\title{
Geohydrology and Simulation of Ground-Water Flow for the Ohio River Alluvial Aquifer near Owensboro, Northwestern Kentucky
}

\section{By MICHAEL D. UNTHANK}

U.S. Geological Survey

Water-Resources Investigations Report 96-4274

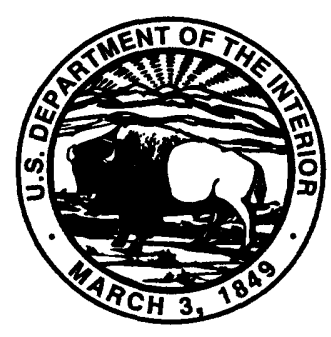




\title{
U.S. DEPARTMENT OF THE INTERIOR \\ BRUCE BABBITT, Secretary
}

\author{
U.S. GEOLOGICAL SURVEY \\ Gordon P. Eaton, Director
}

For additional information write to:

Copies of this report can be purchased from:

District Chief, Kentucky District

U.S. Geological Survey

U.S. Geological Survey

Water Resources Division

Branch of Information Services

9818 Bluegrass Parkway

Box 25286

Louisville, KY 40299

Denver, CO 80225-0286 


\section{CONTENTS}

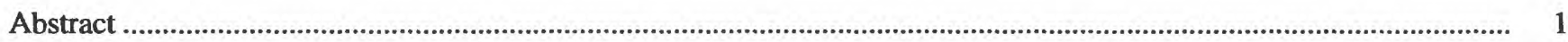

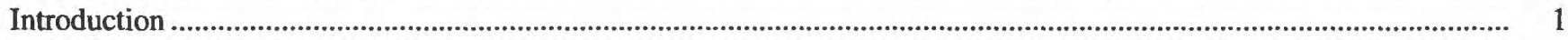

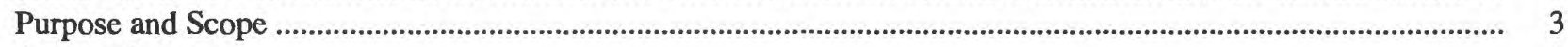

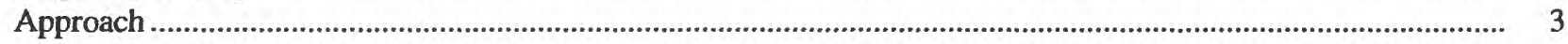

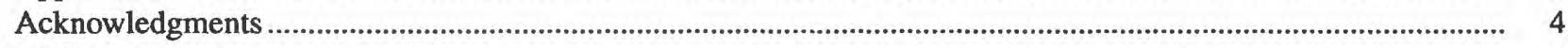

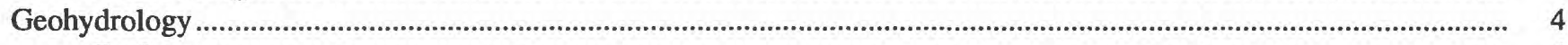

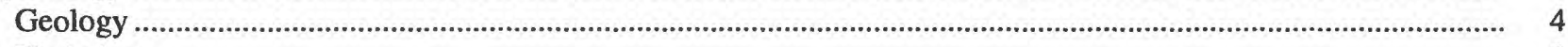

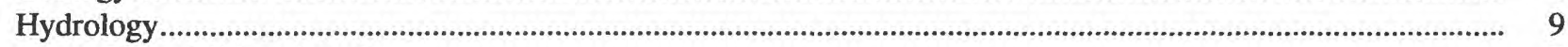

Ground-Water Levels ……………………………………………………………………………………. 9

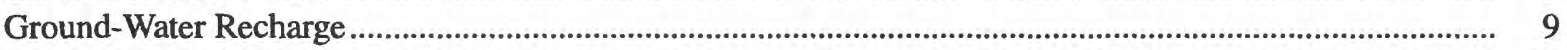

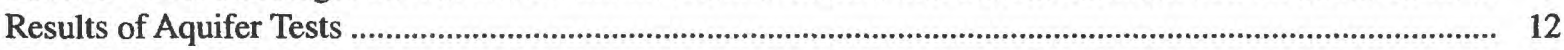

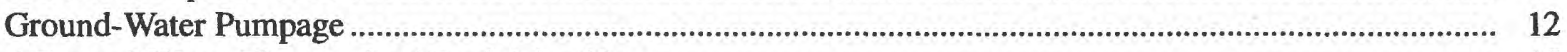

Simulation of Ground-Water Flow in the Alluvial Aquifer......................................................................................... 15

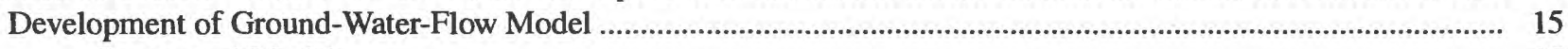

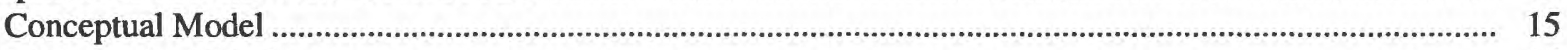

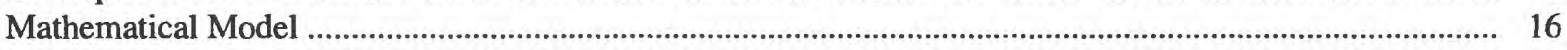

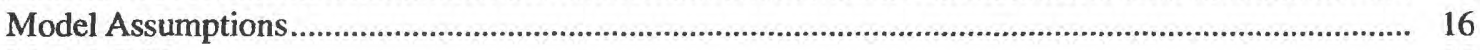

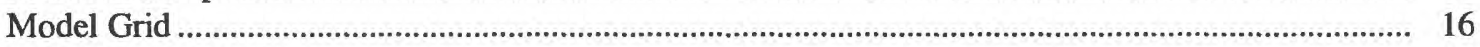

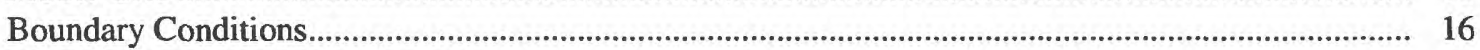

Horizontal Hydraulic Conductivity ................................................................................................. 18

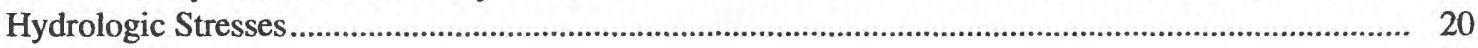

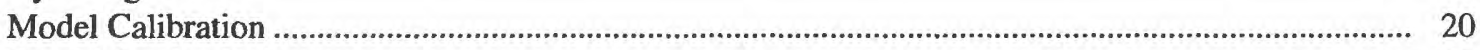

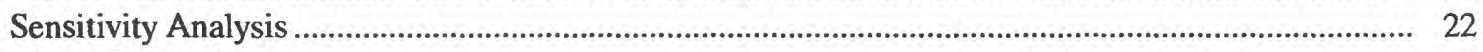

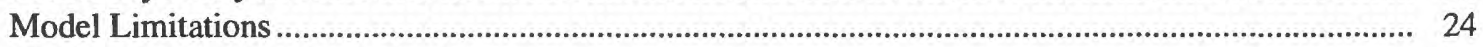

Application of the Ground-Water Flow Model ................................................................................................... 25

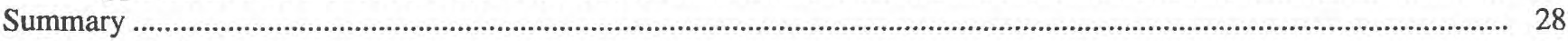

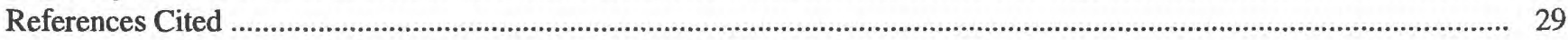

\section{FIGURES}

1. Location of study area and extent of modeled area in the Owensboro area, northwestern Kentucky ..................... 2

2. Diagram showing stratigraphy of major geologic units of the Owensboro area .................................................. 5

3,4. Maps showing:

3. Surficial geology of the Owensboro area

4. Altitude of bedrock surface in the Owensboro area .....................................................................................

5. Generalized geologic section of the alluvial aquifer at Owensboro ................................................................. 8

6-12. Maps showing:

6. Altitude of potentiometric surface of the alluvial aquifer near Owensboro, November 1991 ......................... 10

7. Saturated thickness of the alluvial aquifer near Owensboro, November 1991.............................................. 11

8. Locations of aquifer tests in the Owensboro area.................................................................................... 13

9. Locations of wells with ground-water withdrawals greater than 10,000 gallons per day, Owensboro area, November 1991

10. Extent of finite-difference model grid and boundary conditions for the Owensboro area ............................. 17

11. Areal distribution of horizontal hydraulic conductivity used in model of the alluvial aquifer in the Owensboro area.

12. Measured and simulated heads for wells in the Owensboro area, November 1991 ...

13. Graphs showing sensitivity of simulated heads to changes in recharge, hydraulic conductance, river stage, boundary heads, and boundary conductance, Owensboro area 
14-15. Maps showing:

14. Contributing areas of discharge boundaries computed with the calibrated model,

Owensboro area.

15. Traveltime computed for the Owensboro Municipal Utilities contributing area.

\section{TABLES}

1. Ground-water pumpage for municipal, commercial, and industrial supply wells, Owensboro area, northwestern Kentucky, week of November 14, 1991

2. Estimates of horizontal hydraulic conductivity from well logs and fence diagrams of alluvial deposits, Owensboro area, northwestern Kentucky

3. Simulated components of the ground-water budget for the alluvial aquifer under steady-state conditions, northwestern Kentucky, November 1991

CONVERSION FACTORS AND VERTICAL DATUM

CONVERSION FACTORS

\begin{tabular}{rcl} 
Multiply & By & To Obtain \\
\hline cubic foot per day $\left(\mathrm{ft}^{3} / \mathrm{d}\right)$ & 0.02832 & cubic meter per day \\
cubic foot per second $\left(\mathrm{ft}^{3} / \mathrm{s}\right)$ & 28.32 & liter per second \\
degree Fahrenheit $\left({ }^{\circ} \mathrm{F}\right)$ & ${ }^{\circ} \mathrm{C}=\left({ }^{\circ} \mathrm{F}-32\right) / 1.8$ & degree Celsius \\
foot $(\mathrm{ft})$ & 0.3048 & meter \\
foot per day $(\mathrm{ft} / \mathrm{d})$ & 0.3048 & meter per day \\
foot squared per day $\left(\mathrm{ft}^{2} / \mathrm{d}\right)$ & 0.0929 & meter squared per day \\
foot per mile $\left(\mathrm{ft}^{\prime} / \mathrm{mi}\right)$ & 0.1894 & meter per kilometer \\
gallon per day $(\mathrm{gal} / \mathrm{d})$ & 3.785 & liter per day \\
gallon per minute $(\mathrm{gal} / \mathrm{min})$ & 0.06308 & liter per second \\
gallon per day per square foot $\left.\left[(\mathrm{gal} / \mathrm{d}) / \mathrm{ft}^{2}\right)\right]$ & 40.743 & liter per day per square meter \\
gallon per day per foot $[(\mathrm{gal} / \mathrm{d}) / \mathrm{ft}]$ & 12.418 & liter per day per meter \\
inch $(\mathrm{in})$. & 25.4 & millimeter \\
inch per year $(\mathrm{in} / \mathrm{yr})$ & 25.4 & millimeter per year \\
mile $(\mathrm{mi})$ & 4.38 & liter per second \\
million gallons per day $(\mathrm{Mgal} / \mathrm{d})$ & 1.609 & kilometer \\
square $\mathrm{mile}\left(\mathrm{mi}{ }^{2}\right)$ & 0.09290 & square meter \\
\hline
\end{tabular}

VERTICAL DATUM

Sea level: In this report, "sea level" refers to the National Geodetic Vertical Datum of 1929--a geodetic datum derived from a general adjustment of the first-order level nets of the United States and Canada, formerly called Sea Level Datum of 1929. 


\title{
Geohydrology and Simulation of Ground-Water Flow for the Ohio River Alluvial Aquifer near Owensboro, Northwestern Kentucky
}

\author{
By Michael D. Unthank
}

\section{Abstract}

The Ohio River alluvial aquifer is the primary source of drinking water for the residents of Owensboro and Daviess County and adjacent counties in Kentucky. The aquifer consists of sand and gravel deposits that partly fill a bedrock-valley system consisting of shales of Pennsylvanian age. The valley is a result of dissection by the Ohio River during the Pleistocene epoch. The sand and gravel deposits in the bedrock valley are glacialoutwash deposits of Illinoian and Wisconsin age. The thickness of the alluvium ranges from just a few feet near the bedrock-valley walls to nearly 150 feet in the Bon Harbor Hills area west of Owensboro. Estimates of transmissivity of the alluvium near the Ohio River are in excess of 50,000 gallons per day per foot.

A two-dimensional, steady-state ground-water-flow model was developed to estimate the hydraulic properties, the rate of recharge, and the contributing areas to discharge boundaries for the Ohio River alluvial aquifer near Owensboro. Results from previous studies, available geohydrologic data, and observations of water levels from area ground-water wells were compiled to conceptualize the ground-water-flow system and construct the numerical model. Ground water enters the modeled area primarily by infiltration from precipitation and river leakage towards nearby wells and exits the modeled area primarily by withdrawal wells, flow though the valley across model boundaries, and discharge to the Ohio River. A sensitivity analysis of the model indicates the model is most sensitive to changes in horizontal hydraulic conductivity, especially near the Ohio River boundary. Particle tracking was used to compute the contributing areas to discharge boundaries. Contributing areas for withdrawal wells at Owensboro Municipal Utilities extended south and east toward the valley walls and model boundaries and toward the Ohio River, where most of the water withdrawn by the wells is from induced flow from the river.

\section{INTRODUCTION}

The Ohio River alluvial aquifer is an important water resource for the city of Owensboro, Daviess County, and several adjacent counties in Kentucky (fig. 1). Currently, ground water from the sand and gravel that constitute the aquifer is the only source of drinking water for more than 80,000 people served by the Owensboro Municipal Utilities and the demand for water is projected to increase. A variety of land uses that overlie the alluvial aquifer represent potential sources of ground-water contamination, including above-ground chemical-storage areas, solid and hazardous waste disposal sites, septic tanks, underground storage tanks, urban and industrial 


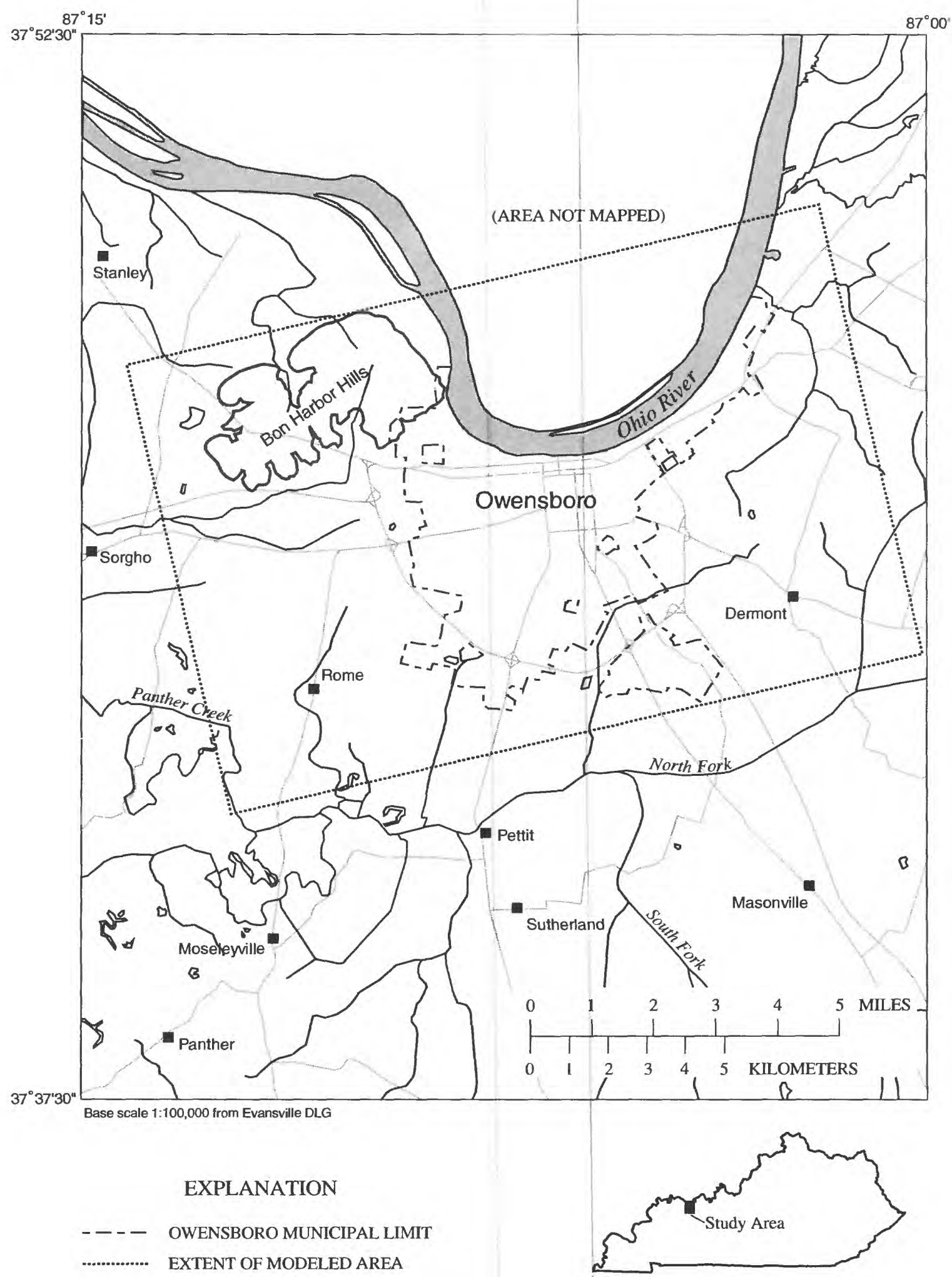

Figure 1. Location of study area and extent of modeled area in the Owensboro area, northwestern Kentucky. 
development, transportation corridors, and agriculture. A better understanding of the ground-water-flow system and a means to evaluate resource-management alternatives are needed to safeguard the water resources of the alluvial aquifer and meet current and future demands on those resources. The U.S. Geological Survey (USGS), in cooperation with the Owensboro Municipal Utilities (OMU), began an investigation in October 1991 to characterize the geohydrology and flow system of the alluvial aquifer in Daviess County.

\section{Purpose and Scope}

This report describes the results of an investigation to refine the understanding of the geohydrology of the alluvial aquifer in the Daviess County area of northwestern Kentucky and to characterize the flow system in the aquifer in the Owensboro area. The hydrologic significance of geologic units in the study area are briefly discussed using results of previous investigations, available hydrologic and lithologic data, and observations of water levels. A conceptualization of the ground-water-flow system is represented in a two-dimensional, steady-state, finite-difference ground-water-flow model. The study was limited to the alluvial aquifer in Daviess County, Kentucky, with emphasis on the Owensboro area.

\section{Approach}

The evaluation of the geohydrology and ground-water-flow in the Ohio River alluvial aquifer at Owensboro, Kentucky consists of a review of published geologic and hydrologic literature, an inventory and measurement of ground-water levels in wells in the study area, a compilation of ground-water pumpage data for the study area, and the testing of geohydrologic concepts of the ground-water-flow system by use of a ground-water-flow model. Previous reports pertaining to the alluvial aquifer at
Owensboro have been part of larger investigations of the alluvial deposits along the entire course of the Ohio River. The geologic history of the Ohio River valley is described by Walker (1957); a reconnaissance of the ground-water resources for the Western Coal Field region is described by Maxwell and Devaul (1962); and Gallaher and Price (1966) characterized the hydrologic system, availability, and development of ground-water supplies of the alluvial deposits along the Ohio River. Information compiled from these investigations provided average hydrologic characteristics for the alluvial aquifer but did not identify local variability in the study area. More detailed information, for example, depth to bedrock, geologic sections, and well logs, is contained on the hydrologic investigations atlas for the Owensboro area by Gallaher (1963). All pertinent information was used to conceptualize the ground-water-flow system of the study area.

The altitude of the water table during November 1991 was determined by conducting a ground-water well inventory in the study area. Ground-water data were retrieved from the USGS database and the Kentucky Division of Water database. Fourteen previously inventoried wells were field-checked and an additional 52 wells were inventoried. Water levels were measured at each well and compiled to draw the potentiometric surface.

Ground-water pumpage data were retrieved from the Kentucky Division of Water's Water Use Program database to supplement water-budget calculations for the study area. Ground-water pumpage data also were field-checked and revised during the ground-water well inventory.

The final part of this evaluation was the design of a ground-water-flow model for the study area. The model serves as a means to formalize the conceptualization of the geohydrologic system as supported by the available information. Inconsistencies between the available data and the conceptualization of the geohydrologic system and areas of sparse or no data are identified. The sensitivity of these inconsistencies and data gaps were 
analyzed by the ground-water-flow model. The particular model documented in this report is a one-layer, finite-difference model using the MODFLOWARC source code of the McDonald and Harbaugh formulation (1988). November 1991 was selected as a time when the ground-water-flow system was assumed to be in equilibrium and was used as a steady-state condition for calibrating the groundwater-flow model.

\section{Acknowledgments}

The author thanks Claude Brown of the Owensboro Municipal Utilities for his assistance in providing well-log and ground-water pumpage data for the OMU well field. The author also thanks personnel from the Kentucky Division of Water, Ground Water Branch, for assistance in collecting water-level data, and those industries that provided ground-water pumpage data.

\section{GEOHYDROLOGY}

The study area lies within the Western Coal Field physiographic region of Kentucky. The exposed consolidated rocks of the area are of sedimentary origin and of Pennsylvanian age. The strata in the Owensboro area dip gently to the west at a slight angle ranging from 15 to $45 \mathrm{ft} / \mathrm{mi}$ (Ray, 1965). The Pennsylvanian rocks lacked resistance to the erosional forces exerted upon them by glacial meltwater of the Pleistocene. Deep valleys were excavated prior to the deposition of a thick body of sand and gravel. The result is a relatively flat flood plain ranging in altitude from 380 to $400 \mathrm{ft}$ above sea level. Its evenness is interrupted by a northeastsouthwest-trending natural levee which stands 25 to $30 \mathrm{ft}$ above the surrounding flood plain (Gallaher and Price, 1966). Ground water in the study area flows from the upland areas surrounding Owensboro towards the Ohio River and the old river channel.
Ground water discharges to the Ohio River and supply wells and flows westward along the drainage of the old river channel.

\section{Geology}

The lithology, structure, and stratigraphy of the Owensboro area were described by Walker (1957), Ray (1965), and Gallaher and Price (1966) and by authors of 7.5-minute geologic and miscellaneous geologic investigations maps (Smith, 1969 and 1971; Carpenter, 1971). Discussion of geologic units in this report is limited to Pennsylvanian shales, and Quaternary deposits of gravel, sand, and loess (fig. 2). The surficial geology of the study area is shown in figure 3 .

The bedrock underlying the unconsolidated deposits of the area is primarily shale of Pennsylvanian age. Outcrops of the Pennsylvanian rocks are few and inconspicuous because of the thick mantle of loess on the uplands and the alluvial deposits in the lowlands (Ray, 1965). The surface of the bedrock is uneven as a result of dissection by the Ohio River during the Pleistocene epoch (fig. 4). Buried cusp-like remnants rise to an altitude of $300 \mathrm{ft}$ above sea level and project outward into the valley in the northeast (Gallaher and Price, 1966). Logs from ground-water wells, core holes, and oil and gas test holes indicate the altitude of the remaining bedrock surface ranges from $240 \mathrm{ft}$ above sea level in the channels of the ancient river to more than $350 \mathrm{ft}$ near the valley walls (Smith, 1969 and 1971; Carpenter, 1971).

The unconsolidated deposits overlying the bedrock are glacial-outwash deposits of Illinoian and Wisconsin age. The thickness of the deposits ranges from about 120 to $130 \mathrm{ft}$ in the study area. The altitude of the buried bedrock surface controls the variation in thickness of the unconsolidated deposits because the land surface is relatively smooth (Gallaher and Price, 1966). 


\begin{tabular}{|c|c|c|c|c|}
\hline SYSTEM & SERIES & FORMATION & $\begin{array}{l}\text { THICKNESS, } \\
\text { in feet }\end{array}$ & DESCRIPTION \\
\hline \multirow{3}{*}{ 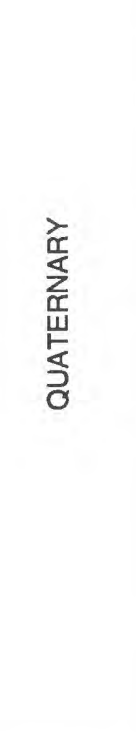 } & \multirow{3}{*}{ 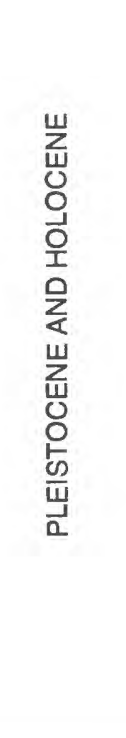 } & ALLUVIUM & $0-100+1-$ & $\begin{array}{l}\text { Sand, silt, clay and gravel: underlying Ohio River } \\
\text { flood plain and occurring along streams }\end{array}$ \\
\hline & & $\begin{array}{l}\text { OUTWASH } \\
\text { DEPOSITS }\end{array}$ & $0-145$ & $\begin{array}{l}\text { Sand, gravel and slit: sand and gravelly sand; } \\
\text { silty to fine sand in upper part, grades downward } \\
\text { into medium sand and gravel. Gravel abundant } \\
\text { in lower part of deposit }\end{array}$ \\
\hline & & LOESS & $0-40$ & $\begin{array}{l}\text { Silt: clayey to finely sandy, non-calcareous in } \\
\text { upper part: contains calcareous nodules in lower } \\
\text { part. Deposited by wind }\end{array}$ \\
\hline \multirow{2}{*}{ 紊 } & 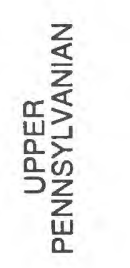 & LISMAN & $0-180+/-$ & $\begin{array}{l}\text { Shale, sandstone, siltstone, coal and limestone: } \\
\text { Shale clayey, thinly laminated, interbedded with } \\
\text { siltstone and sandstone. Two coal beds are present. } \\
\text { The upper coal, No. } 11 \text { coal bed, is less than } 2 \text { feet } \\
\text { thick: the No. } 9 \text { coal bed at the base of the unit is as } \\
\text { much as } 6 \text { feet thick. Limestone locally occurs as } \\
\text { thin lenses in black shale above the No. } 9 \text { coal bed }\end{array}$ \\
\hline & 紊 & CARBONDALE & $190-215$ & $\begin{array}{l}\text { Shale, sandstone, coal and limestone: Shale, black, } \\
\text { clayey to sandy, locally carbonaceous; sandstone, } \\
\text { fine- to coarse-grained, locally carbonaceous. } \\
\text { Several thin, discontinuous coal beds are present. } \\
\text { A thin limestone bed occurs locally below coal beds }\end{array}$ \\
\hline & & & & \\
\hline
\end{tabular}

Figure 2. Stratigraphy of major geologic units of the Owensboro area, northwestern Kentucky (modified from Goudarzi and Smith, 1971). 


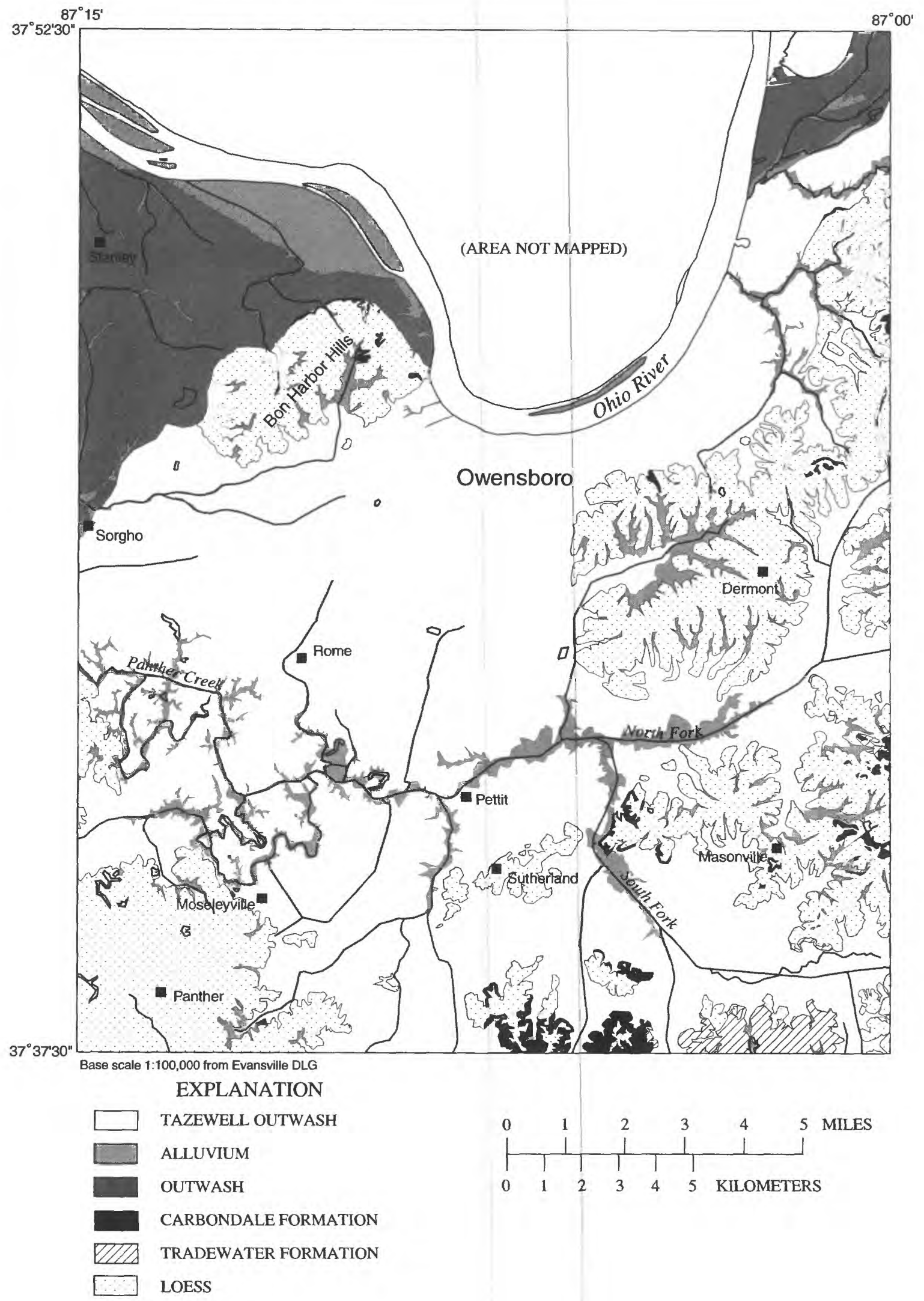

Figure 3. Surficial geology of the Owensboro area, northwestern Kentucky. 


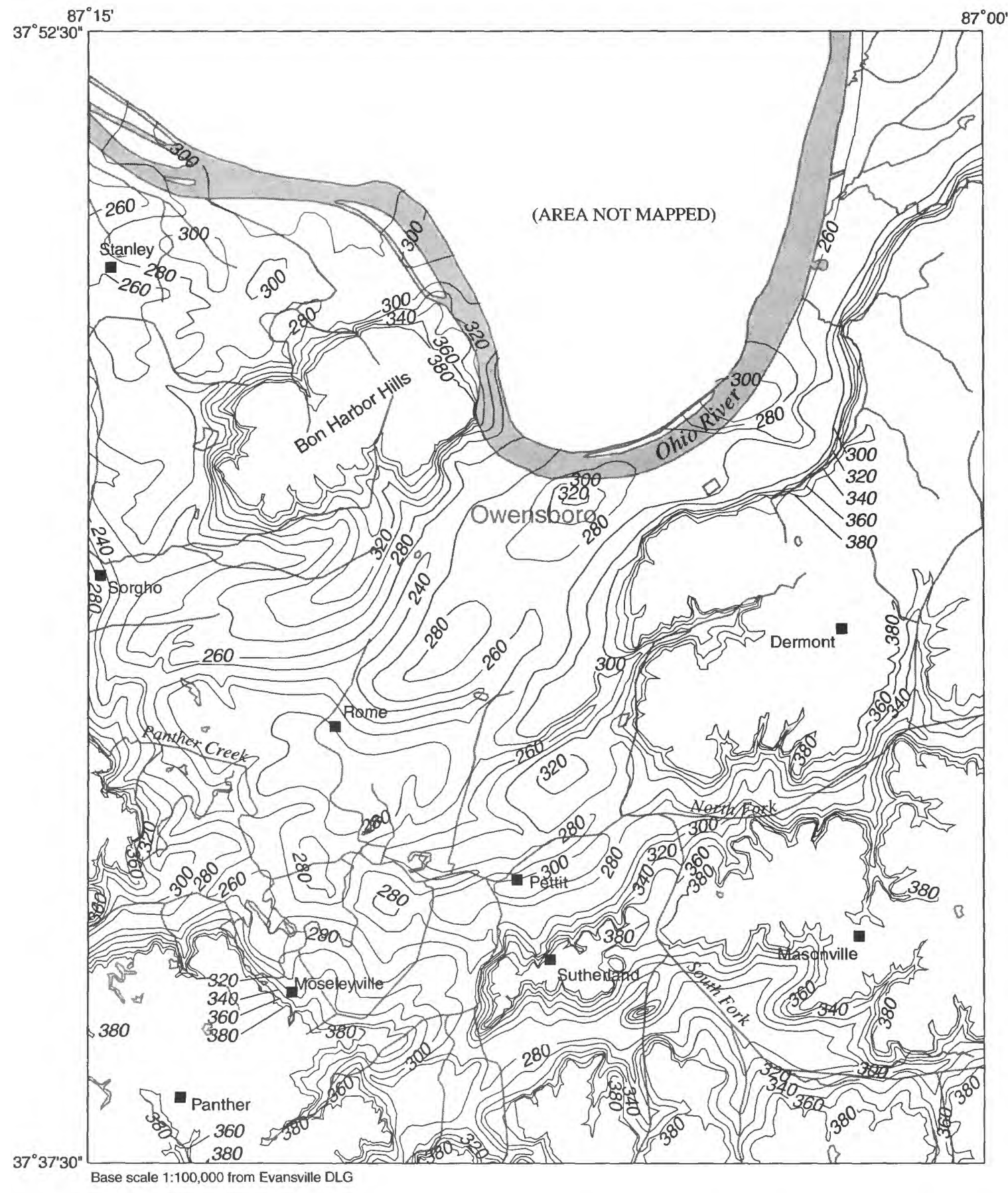

\section{EXPLANATION}

-280 - BEDROCK CONTOUR-Shows altitude of bedrock surface. Contour interval 20 feet. Datum is sea level

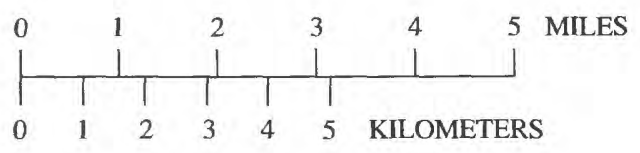

Figure 4. Altitude of bedrock surface in the Owensboro area, northwestern Kentucky. 
The alluvium thins out rapidly to only a few feet in thickness near the bedrock valley walls. The thickest deposits are in the area near the Bon Harbor Hills area, where alluvial deposits are nearly $150 \mathrm{ft}$ thick above the old, deep channel of the Ohio River.

The glacial-outwash deposits are composed generally of two types-upper, fine-grained deposits underlain by coarser sands, gravels, and boulders. The upper, fine-grained deposits near the Ohio River generally are 30 to $50 \mathrm{ft}$ thick. This fine-grained layer thickens and becomes mixed with tributary alluvium as it extends away from the Ohio River.

The basal layer of the outwash is composed of boulder-sized material near the Ohio River to sand or sand and gravel throughout the rest of the study area. The basal sands and gravels thin to just a few feet in thickness or do not exist at all near the bedrock valley walls. The coarse basal section is interrupted near the OMU well field by two extensive clay layers about 10 $\mathrm{ft}$ thick. The first layer lies within a depth range of 35 to $65 \mathrm{ft}$; the other lies just above the bedrock in most places (Gallaher and Price, 1966). Figure 5 shows a generalized geologic section of the alluvial aquifer near the OMU well field.

Pennsylvanian rocks of the Carbondale and Tradewater Formations are covered with deposits of loess. These windblown deposits consist of silt and fine sands derived from the broad, flat flood plains along the river (Maxwell and Devaul, 1962).

Thickness ranges from $3 \mathrm{ft}$ to $20 \mathrm{ft}$ or more in some areas (Ray, 1965).

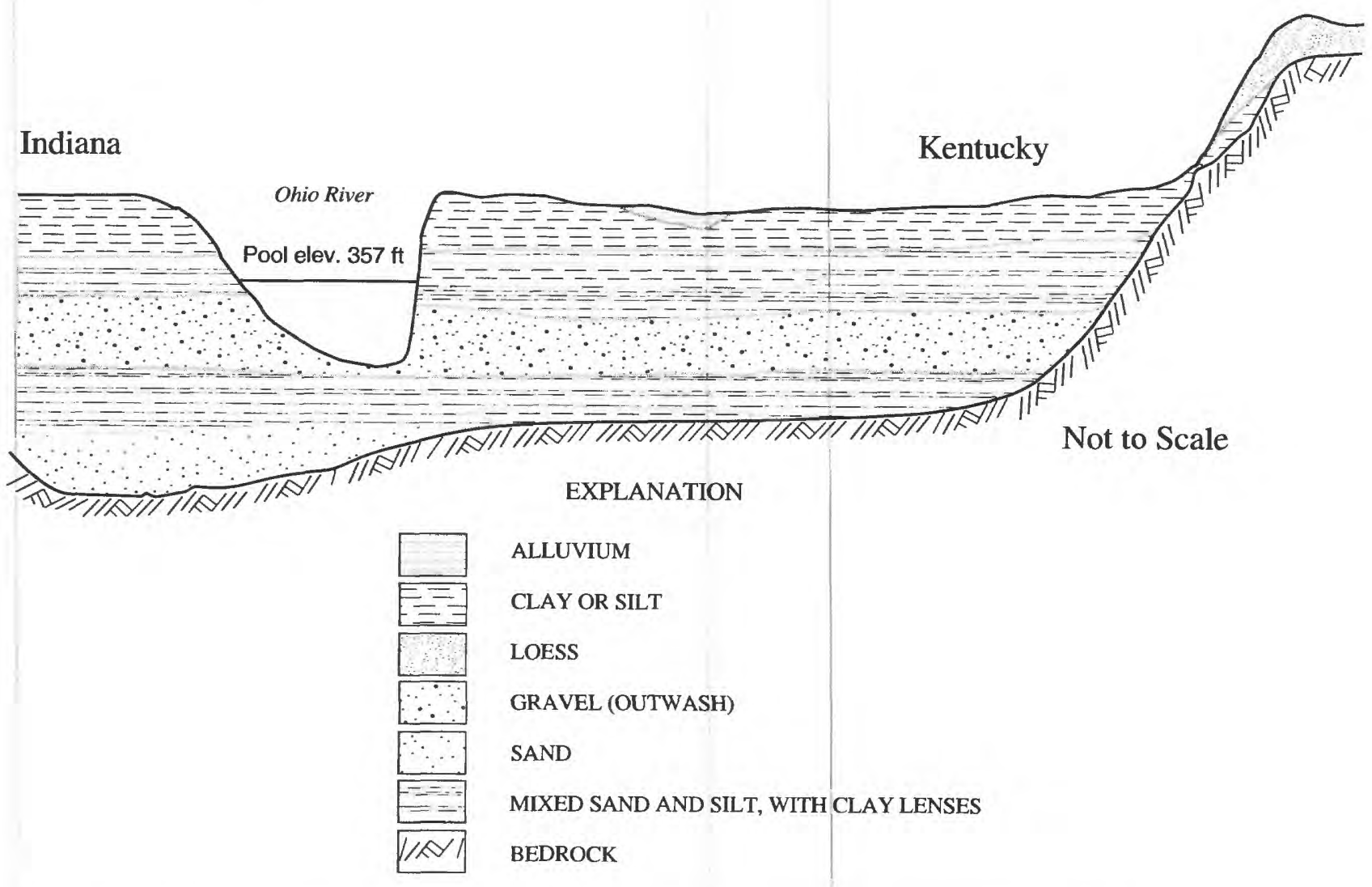

Figure 5. Generalized geologic section of the alluvial aquifer at Owensboro, northwestern Kentucky. 


\section{Hydrology}

Large quantities of water are available to wells drilled in the coarse basal alluvium where the saturated thickness is as much as $110 \mathrm{ft}$ (Gallaher and Price, 1966). A direct connection with the Ohio River also allows for natural and artificially induced infiltration of river water into the alluvial deposits. These two factors combine to make the Ohio River alluvial deposits at Owensboro, Kentucky, a groundwater reservoir of large storage capacity and high yield (Walker, 1957).

\section{Ground-Water Levels}

Ground-water levels were measured at 66 wells - industrial, commercial, public water-supply, and privately owned domestic - during the week of November 14, 1991. These data were used with information about the surficial geology to define the potentiometric surface of the alluvial deposits for November 1991 (fig. 6). The potentiometric surface generally decreases from the valley edges and the Bon Harbor Hills area to areas of discharge, namely the Ohio River with a normal pool elevation of $357 \mathrm{ft}$ (Ohio River datum) and the ancient river channel that drains out the western side of the study area.

Drawdowns in the potentiometric surface near areas of high ground-water pumpage at riverbank well fields show ground-water-level altitudes at or below $340 \mathrm{ft}$ above sea level and considerably below the normal pool elevation of the Ohio River.

When the altitude of the bedrock surface (fig. 4) is subtracted from the altitude of the potentiometric surface (fig. 6) and contoured, the resulting plot is the saturated thickness for the alluvial deposits. Figure 7 shows the saturated thickness contours for the alluvial deposits of the study area for the week of November 14, 1991.

\section{Ground-Water Recharge}

Potential sources of ground-water recharge in the study area are precipitation, floods on the Ohio River, and ground water from the underlying and adjacent bedrock. Average annual precipitation of the Owensboro area is $41.5 \mathrm{in}$. and is fairly evenly distributed throughout the year. Only a small percentage of the precipitation percolates downward to become part of the ground-water-flow system because of losses to overland runoff to surface streams, evaporation, transpiration by plants, and soil moisture uptake.

Rorabaugh (1949) estimated that about 54 percent of the average annual precipitation returns to the atmosphere by evaporation in his study of the Ohio River flood plain at Louisville, Kentucky. More than 18 percent of the remaining precipitation is lost to runoff to surface streams, and about 11 percent is retained as soil moisture to be lost later by evapotranspiration. Thus, about 17 percent of the average annual precipitation percolates downward and recharges the ground-water-flow system. Rorabaugh's study was made of a relatively undeveloped area where the coarse basal alluvium is overlain by 5 to $40 \mathrm{ft}$ of fine to very fine sand, silt, and clay. The study's results are applicable to the Owensboro area because of the similarity in the characteristics of the alluvial deposits, however, surface enhancements, for example, pavement, stormwater drainage, and cropland in the Owensboro area would further reduce the proportion of precipitation that recharges the ground water.

Gallaher and Price (1966) state that most of the water that recharges the aquifer along the Ohio River enters the ground during the winter and early spring when precipitation is high and the river is overflowing its banks because of melting snow upstream. The steep riverbank at Owensboro precludes seasonal flooding contributions except under extreme high-water conditions, but water from the Ohio River is a source of recharge to the ground-water-flow system in the areas of high ground-water pumpage along the riverbank. Cones of depression are formed in the potentiometric surface where ground-water withdrawal wells are pumped (fig. 6). When the cone reaches the Ohio River, water from the river is induced into the alluvial deposits. 


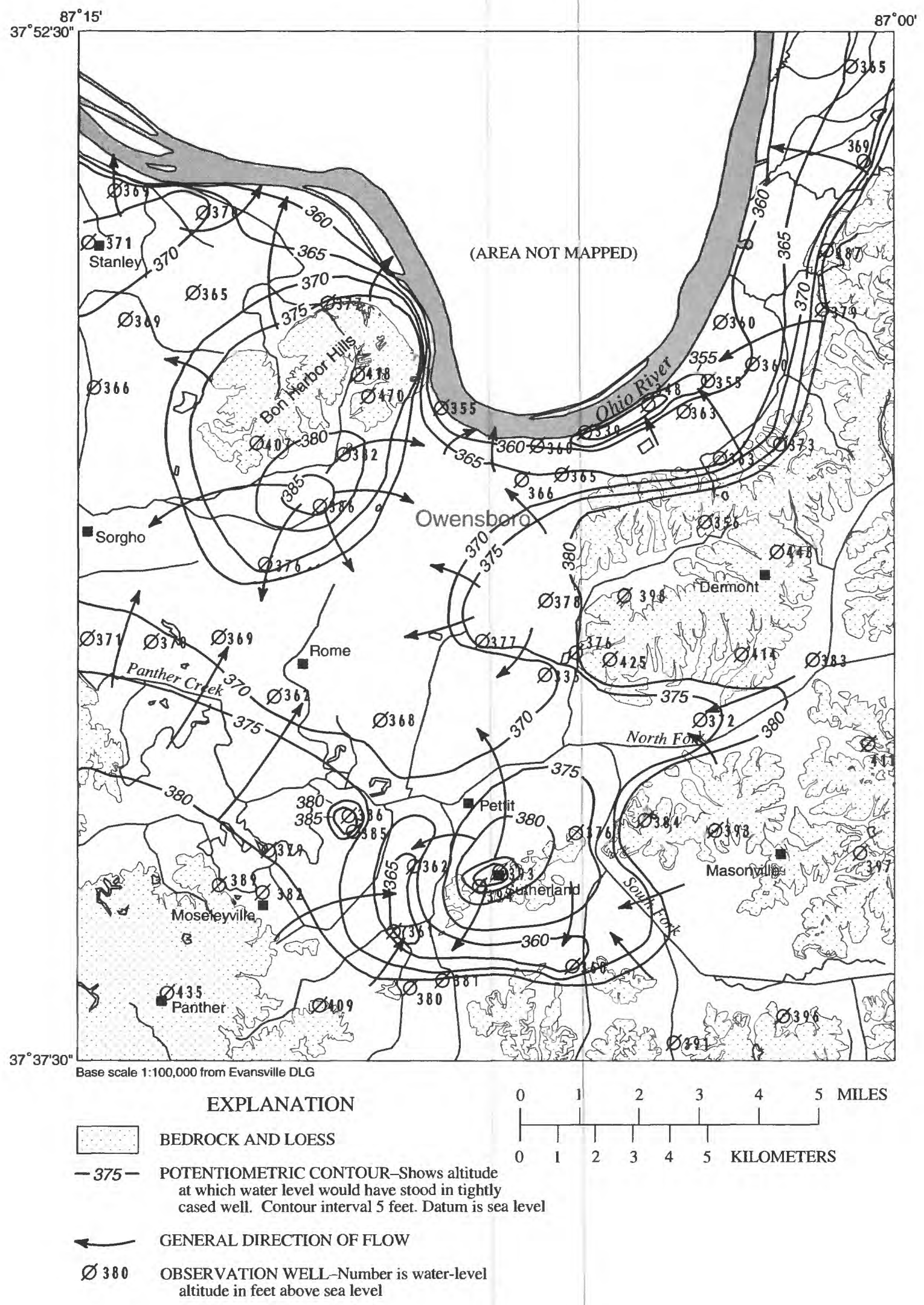

Figure 6. Altitude of potentiometric surface of the alluvial aquifer near Owensboro, northwestern Kentucky, November 1991. 


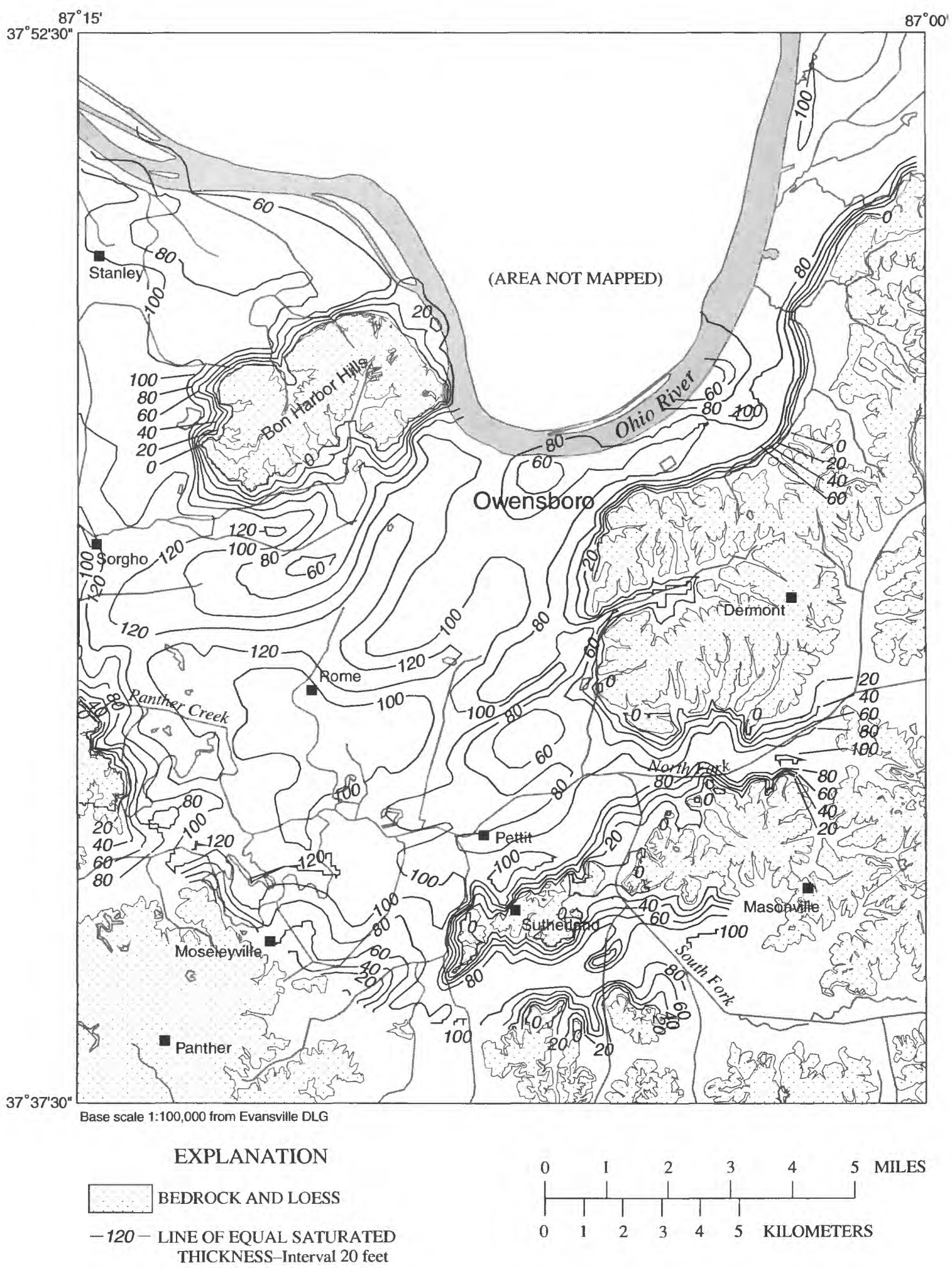

Figure 7. Saturated thickness of alluvial aquifer near Owensboro, northwestern Kentucky, November 1991. 
Induced infiltration of river water recharges the ground-water-flow system and allows for high sustained well yields of nearly $1,000 \mathrm{gal} / \mathrm{min}$ (Gallaher and Price, 1966).

Another potential source of recharge to the ground-water-flow system is water discharging from the bedrock underlying and adjacent to the alluvial deposits. The bedrock underlying the outwash is primarily shale of Pennsylvanian age and is not thought to contribute a significant amount of recharge to the overlying deposits. No wells were found during this investigation that were screened in the underlying shale. Several water-level measurements were made at wells screened in the adjacent shale of the valley walls. Water-level altitudes were generally higher in the upland regions than those in the outwash, indicating that the upland regions could be a source of recharge.

\section{Results of Aquifer Tests}

Few results of aquifer tests that could be used to characterize the hydrologic properties of the Ohio River alluvial aquifer at Owensboro are published or documented. The locations of aquifer tests conducted in the study area for which results are on file in the USGS, Kentucky District office are shown in figure 8. A single-well aquifer test, conducted at the OMU well field, showed a transmissibility coefficient of $55,300(\mathrm{gal} / \mathrm{d}) / \mathrm{ft}$ (7,410 ft/d) (Gallaher and Price, 1966). Other aquifer tests conducted at the Green River Steel plant and the Fleischmann Distillery computed transmissibility coefficients of 43,000 and 23,000 (gal/d)/ft $(5,800$ and $3,100 \mathrm{ft} / \mathrm{d})$, respectively.

Tests of unsaturated samples of aquifer material collected at various depths on the riverbank indicate an average permeability coefficient of 525 (gal/d) ft $(70 \mathrm{ft} / \mathrm{d})$. Permeabilities ranged from 570 to 140,000 (gal/d)/ft (77 to $19,000 \mathrm{ft} / \mathrm{d}$ ) for four disturbed samples of alluvium collected at depths of 86 to $128 \mathrm{ft}$ (Gallaher and Price, 1966).

\section{Ground-Water Pumpage}

A total of nearly $20 \mathrm{Mgal} / \mathrm{d}$ of ground water was being pumped in the study area during the week of November 14, 1991. At OMU's well field, which consists of 39 wells, $14.3 \mathrm{Mgal} / \mathrm{d}$ was pumped from 19 wells during this period. Additional pumping in the study area ranged from $0.04 \mathrm{Mgal} / \mathrm{d}$ from two wells at the Texas Gas Transmission Corporation to 2.0 Mgal $/ \mathrm{d}$ at the W.R. Grace and Company well field. Ground-water pumpage for facilities in the Owensboro area whose withdrawals are greater than $10,000 \mathrm{gal} / \mathrm{d}$ are summarized in figure 9 and table 1 .

All municipal supply wells and most of the industrial and commercial supply wells are in heavily pumped areas of the aquifer along the Ohio River (fig. 9). Coarse aquifer material, saturated thicknesses ranging from 60 to $100 \mathrm{ft}$, and the capability of inducing infiltration of river water allow for high, sustained well yields. Gallaher and Price (1966) reported well yields along the Ohio River generally range from 400 to $1,000 \mathrm{gal} / \mathrm{min}$ with most wells being pumped at rates from 700 to $800 \mathrm{gal} / \mathrm{min}$. Drawdowns at these pumping rates are not excessive and specific capacities range from 13 to 75 ( $\mathrm{gal} / \mathrm{min}$ )/ft. But high well yields are not limited to these riverbank well fields, as shown by the well at the Owensboro Country Club (fig. 9). The yield of the 123-foot-deep well was $725 \mathrm{gal} / \mathrm{min}$ (Gallaher and Price, 1966).

Table 1. Ground-water pumpage for municipal, commercial, and industrial supply wells, Owensboro area, northwestern Kentucky, week of November 14, 1991

[Data from the Kentucky Water Use Permit File]

\begin{tabular}{lcc}
\hline Ground-water user & $\begin{array}{c}\text { Pumpage } \\
\text { (Mgal/d) }\end{array}$ & $\begin{array}{c}\text { Number of } \\
\text { wells }\end{array}$ \\
\hline Field Packing Co. ........................ & 1.9 & 3 \\
Green River Steel....................... & 1.0 & 7 \\
Owensboro Country Club.............. & .08 & 6 \\
Owensboro Grain Co.................... & .6 & 3 \\
Owensboro Municipal Utilities ........ & 14.3 & 39 \\
Owensboro-Daviess Co. & & \\
Hospital ................................. & .05 & 1 \\
Texas Gas Transmission Co............ & .04 & 2 \\
W.R. Grace and Co.......................... & 2.0 & 6 \\
\hline
\end{tabular}




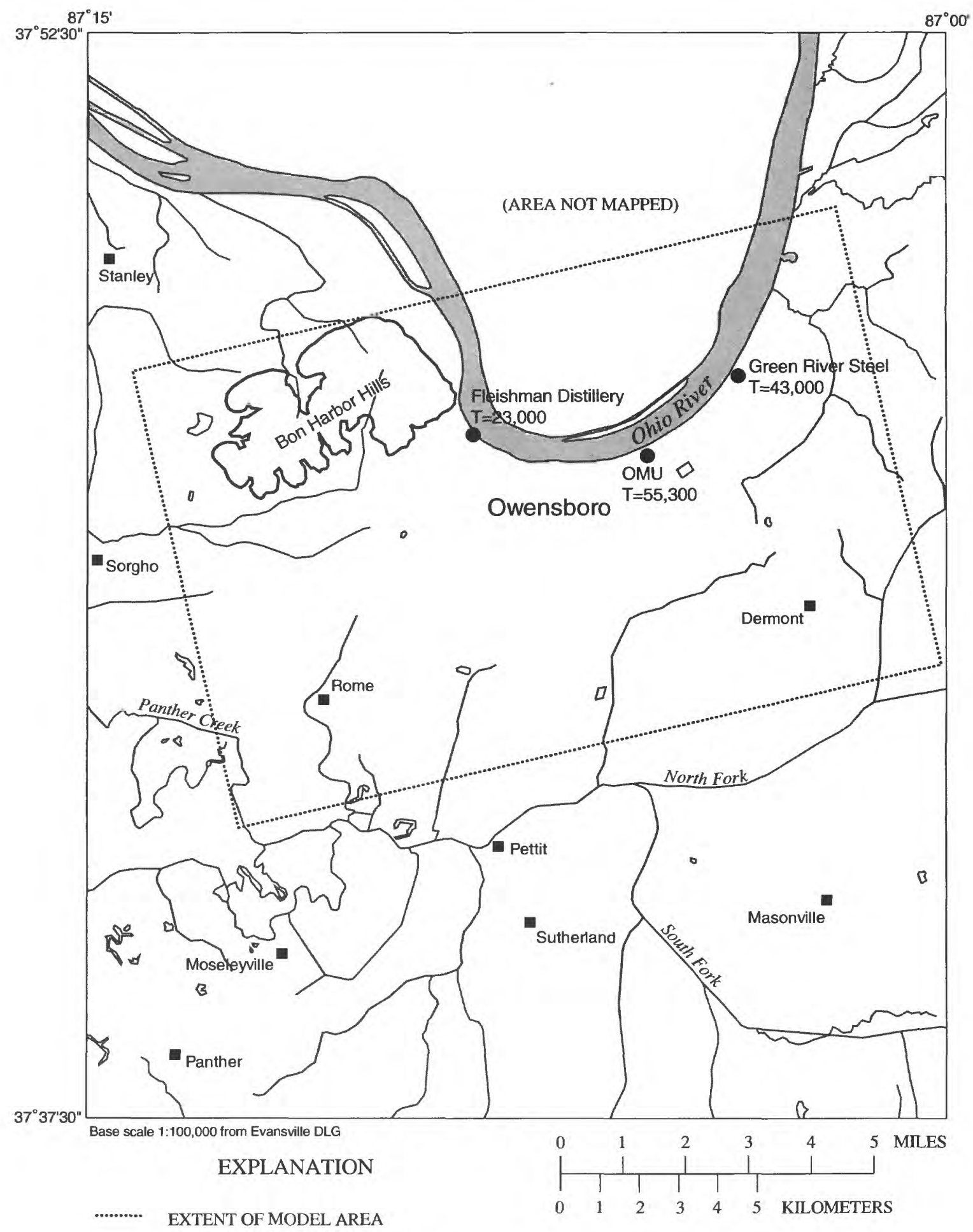

LOCATION OF AQUIFER TEST-T,

transmissibility in gallons per day per foot

Figure 8. Locations of aquifer tests in the Owensboro area, northwestern Kentucky. 


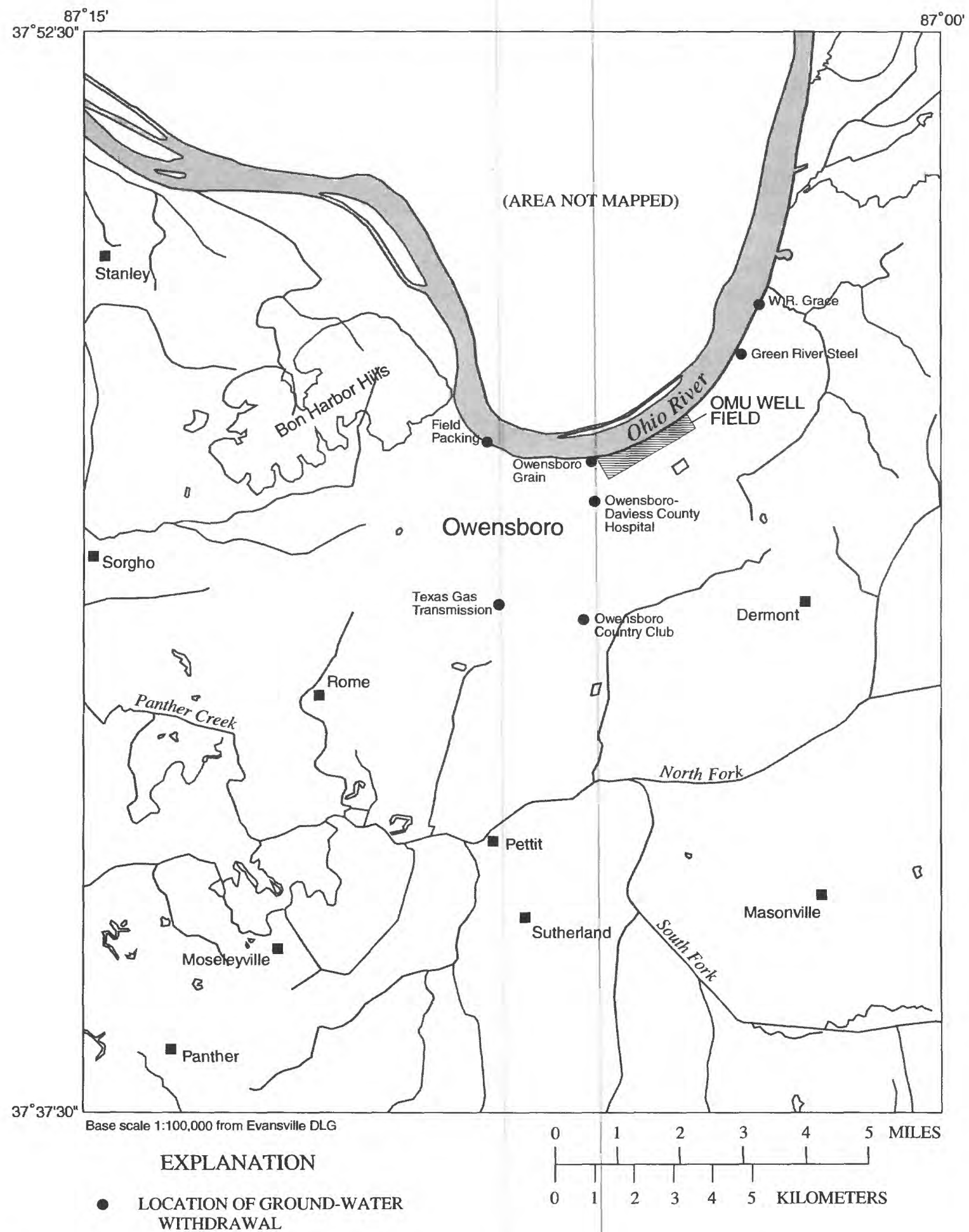

Figure 9. Locations of wells with ground-water withdrawals greater than 10,000 gallons per day, Owensboro area, northwestern Kentucky, November 1991. 


\section{SIMULATION OF GROUND-WATER FLOW IN THE ALLUVIAL AQUIFER}

\section{Development of Ground-Water-Flow Model}

A modified form of the USGS (McDonald and Harbaugh, 1988) modular, three-dimensional, finitedifference, ground-water-flow model, commonly referred to as MODFLOW, was used to construct a regional, two-dimensional, steady-state model of the ground-water-flow system at Owensboro, Kentucky. The MODFLOW program was used to simulate flow in a one-layer representation of the ground-water-flow system assuming unconfined, steady-state conditions. The modified version of MODFLOW that was used is called MODFLOWARC (Orzol and McGrath, 1992). MODFLOWARC does not perform any data modifications or transformations, but facilitates the use of a geographic information system (GIS) for input to the MODFLOW program. The MODFLOW program uses finite-difference formulations and an iterative algorithm (Strongly Implicit Procedure for this application) to solve the ground-water-flow equations at discrete and regularly arranged points. The solution is only an approximation because of three factors: most of the input data is estimated spatially and quantitatively within an acceptable range of hydrologically reasonable values based on measured data; the formulations are solved discretely rather than continuously; and, the solution method is iterative and computations are stopped once the userdefined tolerance is met (Dumouchelle and others, 1993). A head-change criterion for convergence of $0.01 \mathrm{ft}$ was set for the Owensboro model, meaning iteration stops when the maximum absolute value of head change from all nodes during an iteration is less than or equal to $0.01 \mathrm{ft}$.

The study area is divided into a grid of rectangular cells. Each cell is assigned hydrologic parametric values at the center of the cell, or node. Aquifer properties are assumed to be uniform throughout the cell. Likewise, external stresses are applied to the entire cell at the node. Depending on the size of the cell, the model may not be able to accurately simulate localized flows or water levels. As the cell size increases, the effect of a stress is averaged over a larger area and detail decreases. The MODFLOW program calculates the hydraulic head at each node and the volumetric flux between cells. Horizontal flow within the model is assumed to be directly proportional to the hydraulic-head gradient.

By using the MODFLOWARC version of the MODFLOW program, most of the data required for model operation was transferred directly from ARC/Info coverages to the ground-water-flow model data files. MODFLOWARC uses ARC/Info to process non-gridded hydrogeologic data into the gridded format required for input to the MODFLOW program. This data compilation approach enables the user to graphically display and edit the gridded data prior to model operation (preprocessing) and graphically display the results from the model simulation (post-processing). ARC/Info is a vectorbased geographical information system.

\section{Conceptual Model}

A preliminary step in designing a groundwater-flow model is to devise a conceptual model of the flow system. The conceptual model is a simplified representation of the important hydrogeologic conditions of the natural flow system. Field-based data such as aquifer characteristics, ground-water levels, and infiltration rates are measured or estimated to provide a clear and easily understood physical picture of the flow system. Errors in the development of the conceptual model can result in the failure of the mathematical model to make accurate predictions.

The study area encompasses about $95 \mathrm{mi}^{2}$ of alluvial deposits near Owensboro. The focal point of the model is an area of high ground-water pumpage that includes riverbank well fields of OMU, Owensboro Grain Company, Green River Steel, and the W.R. Grace Company (fig. 9). Pumpage in this area exceeded $16 \mathrm{Mgal} / \mathrm{d}$ in November 1991.

Two distinct flow patterns exist within the alluvial deposits of the study area. Under natural conditions, the regional ground-water flow pattern is predominately horizontal and from the alluvium/bedrock boundaries (valley walls) towards the Ohio River which is in direct connection with the 
alluvial aquifer. Sources of recharge for the alluvial aquifer are precipitation and discharge from the valley walls. This pattern is interrupted by ground-water withdrawals from the riverbank well fields. Cones of depression are formed in the potentiometric surface (fig. 6) and extend to the river. This induced infiltration provides an additional source of water to the alluvial aquifer. The shale underlying the alluvial deposits is dense and considered impermeable, thus forming a no-flow boundary throughout the modeled area. Surface-water drainage by Panther Creek is not thought to interact closely with the regional flow system.

\section{Mathematical Model}

The mathematical model is formed from a set of partial-differential equations - governing equation, boundary conditions, and initial conditions. Numerical methods are used to solve a set of algebraic equations generated by approximating these equations. A general form of the partial-differential equation governing two-dimensional, steady-state ground-water flow in a heterogeneous, isotropic, unconfined aquifer is:

$$
\frac{\partial}{\partial x}\left(T \frac{\partial h}{\partial x}\right)+\frac{\partial}{\partial y}\left(T \frac{\partial h}{\partial x y}\right)=W,
$$

where

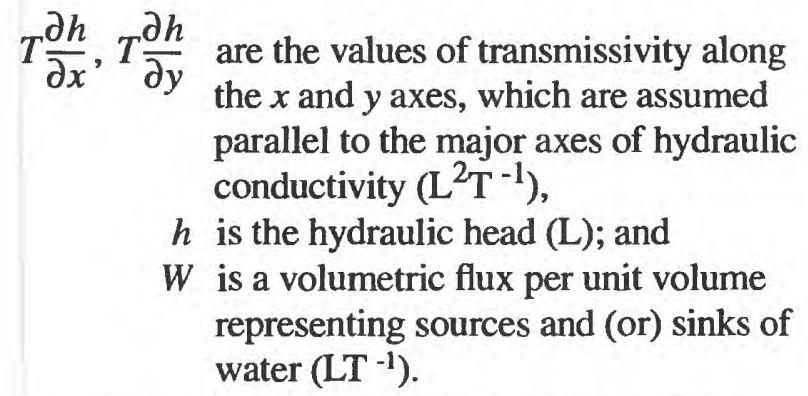

Boundary conditions and initial conditions were selected to represent hydraulic conditions as formulated in the conceptual model. The governing equation, boundary conditions, and initial conditions were combined in a set of finite-difference equations and solved numerically using MODFLOW.

\section{Model Assumptions}

The ground-water-flow model was designed in accordance with the following assumptions:

1. The modeled area is at steady state; the flow system does not have a net gain or loss of water.

2. The shale beneath the alluvial deposits is not an aquifer and therefore is not included in the model design as an active layer. The shale in the bedrock valley walls is included in the model.

3. All simulated wells are assumed to fully penetrate the alluvial deposits.

4. Horizontal hydraulic conductivity is uniform with depth but varies areally.

5. Infiltration from precipitation is at a constant rate and does not vary areally.

6. The Ohio River is hydraulically connected to the alluvial aquifer throughout its course in the modeled area.

\section{Model Grid}

The grid design used to model the groundwater-flow system is shown in figure 10 . The grid is comprised of 35 rows and 58 columns; grid orientation is 13 degrees west of north. Cell size is variable with the smallest cells in the area of interest surrounding the OMU well field and nearby groundwater withdrawal sites. Cells near these pumping centers are about $165 \times 165 \mathrm{ft}$. Cells outside of this area are variably spaced with a maximum size of about $4,920 \times 4,920 \mathrm{ft}$. The ground-water-flow system is modeled as a single layer.

\section{Boundary Conditions}

The Ohio River and the bedrock valley walls were two of the natural hydrologic boundaries used to formulate lateral boundaries of the modeled area. Where there were no natural hydrologic boundaries present, head-dependent boundaries were designed on the basis of the potentiometric surface of the ground water. Boundary conditions for the modeled area are shown in figure 10. 


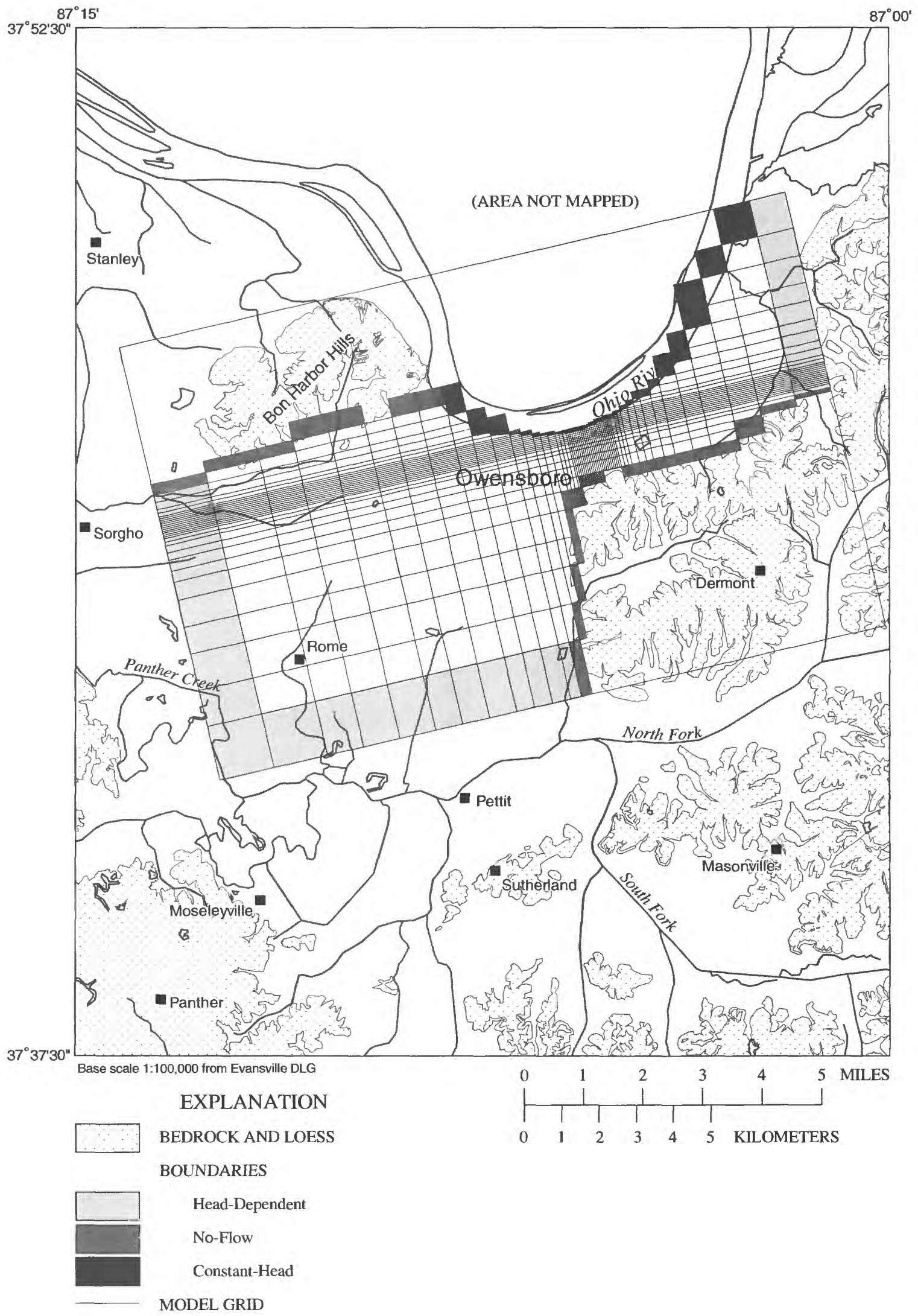

Figure 10. Extent of finite-difference model grid and boundary conditions for the Owensboro area, northwestern Kentucky. 
The Ohio River was modeled as a constanthead boundary for the simulation because of the large quantity of flow available from the river and its direct connection to the alluvial aquifer in the modeled area. The altitude of the Ohio River stage during the collection of ground-water-level data was $357 \mathrm{ft}$ above sea level. Stage data for the Ohio River was collected at a USGS gaging station operated at Cannelton Dam, about 30 mi upstream from Owensboro.

Flow contributions from the bedrock valley walls were calculated using the Darcy equation and estimated values of hydraulic conductivity for the bedrock formations. The conductance, $\mathrm{C}$, in the model cells representing the head-dependent boundaries was computed from the relation

$$
C=K A / L \text {, }
$$

where

$K$ is the hydraulic conductivity of the bedrock material (LT),

$A$ is the cross-sectional area perpendicular to the flow $\left(\mathrm{L}^{2}\right)$, and

$L$ is the length of the flow path between the center of the cell and the model boundary (L).

An arbitrary hydraulic conductivity of $10 \mathrm{ft} / \mathrm{d}$ was used for the bedrock formations.

The remaining lateral boundaries were modeled as head-dependent boundaries and used the above relation for the computation of conductance. The potentiometric-surface map of the ground water (fig. 6) was used to determine changes in head and flow direction across the boundaries. Values of hydraulic conductivity for aquifer material outside of the modeled area were assigned the same hydraulic conductivity as the adjacent model cell.

\section{Horizontal Hydraulic Conductivity}

Data detailing the hydrologic characteristics of the alluvial aquifer in the study area are sparse. An aquifer test conducted at the OMU well field showed a transmissibility coefficient of $55,300(\mathrm{gal} / \mathrm{d}) / \mathrm{ft}$ (Gallaher, 1993; Gallaher and Price, 1966). With a saturated thickness of about $100 \mathrm{ft}$, horizontal hydraulic conductivity is estimated to be $74 \mathrm{ft} / \mathrm{d}$. Other aquifer test results on file at the USGS, Kentucky District office include testing at the Green River Steel plant (hydraulic conductivity equaled 430 $\mathrm{ft} / \mathrm{d}$ ) and the Fleischmann Distillery (hydraulic conductivity equaled $230 \mathrm{ft} / \mathrm{d}$ ). All of these aquifer tests were conducted on riverbank wells; aquifer tests on wells outside of riverbank well fields is lacking.

Estimates of horizontal hydraulic conductivity for the alluvial deposits in the Owensboro area are summarized in table 2. The alluvial deposits were classified from silty/clayey sand to sandy gravel based on well logs and fence diagrams as presented by Gallaher (1963). Horizontal hydraulic conductivity was assigned to each classification based on the aquifer test results from the riverbank wells. Each model cell was assigned a horizontal hydraulic conductivity as shown in figure 11 .

Table 2. Estimates of horizontal hydraulic conductivity from well logs and fence diagrams of alluvial deposits, Owensboro area, northwestern Kentucky

[ft/d, foot per day]

\begin{tabular}{|c|c|}
\hline $\begin{array}{c}\text { Generalized geologic } \\
\text { description }\end{array}$ & $\begin{array}{l}\text { Horizontal hydraulic } \\
\text { conductivity } \\
\text { (ft/d) }\end{array}$ \\
\hline 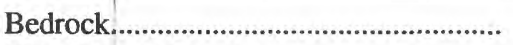 & 10 \\
\hline Silt, clay, and sand & $75-80$ \\
\hline 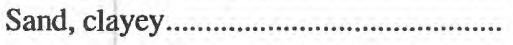 & $85-90$ \\
\hline Clay and sand & $125-130$ \\
\hline Clay, sand, and gravel............................... & $145-150$ \\
\hline Sand & $155-160$ \\
\hline 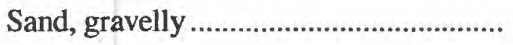 & 315 \\
\hline 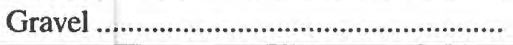 & 325 \\
\hline
\end{tabular}




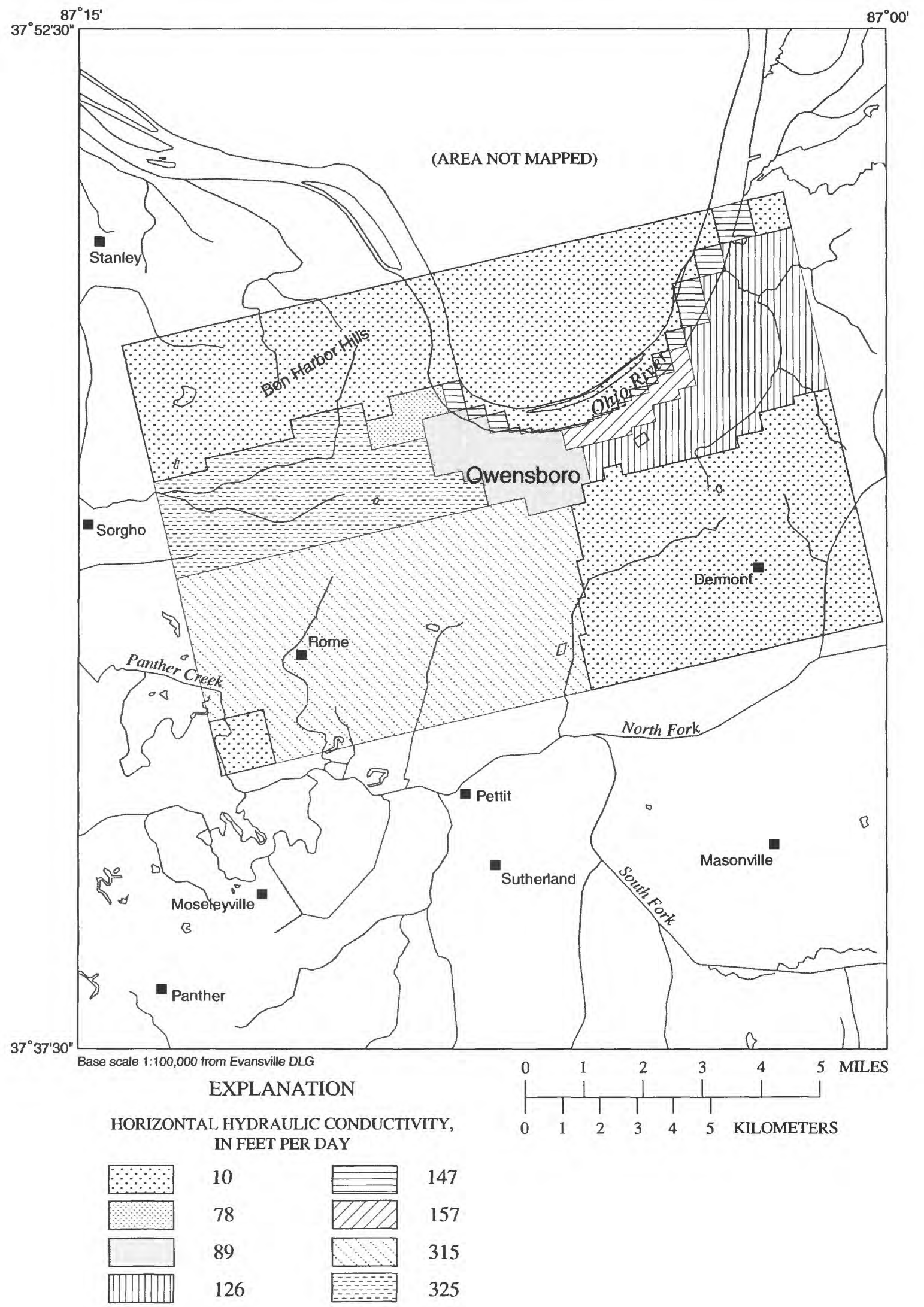

Figure 11. Areal distribution of horizontal hydraulic conductivity used in model of the alluvial aquifer in the Owensboro area, northwestern Kentucky. 


\section{Hydrologic Stresses}

Recharge from precipitation, pumping of ground water, and the stage of the Ohio River are the hydrologic stresses accounted for in the simulation of the ground-water-flow system. Recharge is limited to the amount of precipitation that reaches the groundwater-flow system once estimates for overland runoff, evapotranspiration, and soil moisture uptake have been subtracted. Of the $41.5 \mathrm{in}$. of average annual precipitation, $3.5 \mathrm{in} / \mathrm{yr}$, or about 8.5 percent, were estimated to recharge the ground-water-flow system. This is less than the $7 \mathrm{in} / \mathrm{yr}$ ( 17 percent) estimated by Rorabaugh (1949) for the Louisville area due to more paved area, existence of stormwater drainage structures, and agricultural uptake in the Owensboro area. Pumpage totals for area ground-water users were collected during the week of November 14, 1991. OMU records showed a total of $14.3 \mathrm{Mgal} / \mathrm{d}$ pumped from a total of 19 wells. For the simulation, the total was divided equally between the pumping wells. Locations of well fields pumping greater than $10,000 \mathrm{gal} / \mathrm{d}$ in November 1991 are shown in figure 9. Lastly, the normal pool elevation of the Ohio River at Owensboro ranges from 357 to $358 \mathrm{ft}$ above sea level. The pool stage is maintained through a system of locks and dams with Owensboro located about midway between Cannelton Locks and Dam (upstream) and Newburgh Locks and Dam (downstream). The river stage was held at $357 \mathrm{ft}$ above sea level for the simulation.

\section{Model Calibration}

The model was calibrated to assumed steady-state conditions for November 1991.

Calibration of the model was based entirely on best-fit analyses of simulated and measured hydraulic heads for 19 ground-water wells in the model's boundaries. The summary statistics of root-mean-square error (RMSE), average absolute head difference ( $A A H D)$, and average head difference $(A H D)$ were used in the calibration process to quantify the accuracy of the calibration.
The RMSE accounts for variance and bias of the compared data, and is calculated as

where

$$
R M S E=\sqrt{\sum_{i=1}^{N} \frac{\left(h_{c a l_{i}}-h_{m_{i}}\right)^{2}}{N}},
$$

$$
\begin{gathered}
h_{\text {cal }_{i}} \text { is the simulated head, } \\
h_{m_{i}} \text { is the measured head, and } \\
N \text { is the number of measurements used in } \\
\text { error computations. }
\end{gathered}
$$

The term $h_{\text {cal }_{i}}-h_{m_{i}}$ is known as the head difference or residual head. The variance of the compared data is indicated by $A A H D$ also, which is calculated as

$$
A A H D=\sum_{i=1}^{N} \frac{a b s\left(h_{\mathrm{cal}_{i}}-h_{m_{i}}\right)}{N},
$$

where

$a b s$ indicates the absolute value of the expression in parentheses. Low values of RMSE and AAHD indicate low variance, and therefore, high correlation (Dumouchelle and others, 1993). The degree of skewness in the compared data is shown in $A H D$, which is calculated as

$$
A H D=\sum_{i=1}^{N} \frac{\left(h_{c a l_{i}}-h_{m_{i}}\right)}{N} .
$$

A low absolute value of $A H D$ indicates an even spread of simulated results around the measured-head data. As simulated heads approach measured heads, these three statistical values approach zero.

Simulated and measured hydraulic heads at the 19 wells are shown in figure 12 . Overall, the simulated heads match reasonably well with the measured heads. The calibration simulation resulted in a RMSE of 2.82, an AAHD of 2.42, and an AHD equal to -0.42 . Larger discrepancies are found in areas of high ground-water pumpage (greater than 1 $\mathrm{Mgal} / \mathrm{d}$ ), large cell sizes (greater than 1,000 m), or a combination of both. 


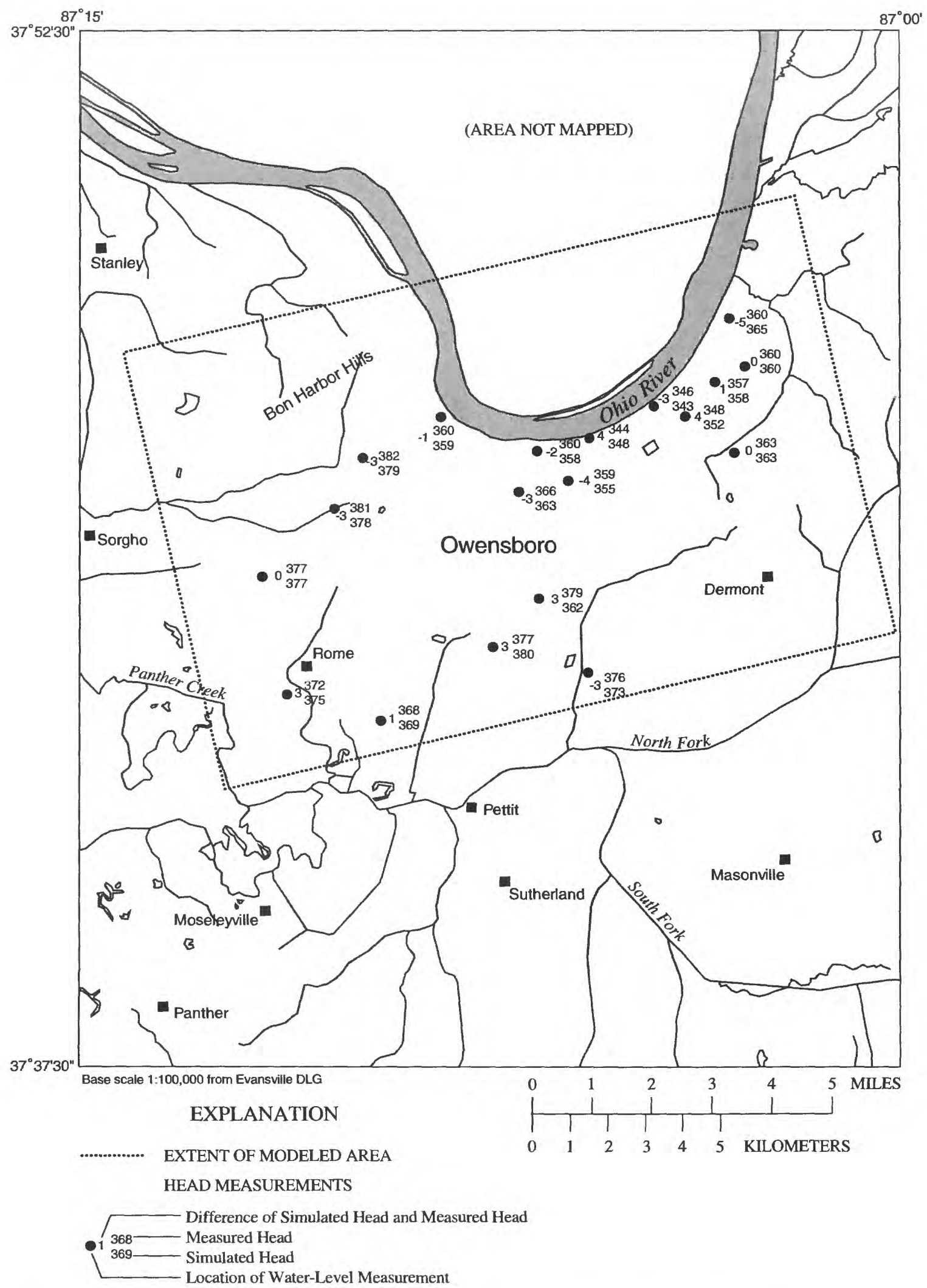

Figure 12. Measured and simulated heads for wells in the Owensboro area, northwestern Kentucky, November 1991. 
In addition to simulated heads, the calibrated steady-state model provided a simulated groundwater budget for the aquifer (table 3 ). The simulation indicated that, of the total recharge to the alluvial aquifer, induced infiltration from the Ohio River provided about 68 percent, precipitation provided about 26 percent, and flow across the valley wall boundary provided about 6 percent. Ground-water withdrawals accounted for about 86 percent of the discharge from the alluvial aquifer, flow across the model boundary towards the ancient river channel drainage provided about 13 percent, and flow from the aquifer to the Ohio River accounted for about 1 percent.

\section{Sensitivity Analysis}

Sensitivity analysis is a procedure to assess how responsive the calibrated model is to systematic changes in each input parameter. The analysis determines which parameters exert the most control over the model solution and possibly generate the largest error when miscalculated. Parameters that were varied in the sensitivity analysis include hydraulic conductivity, recharge, river stage, and

Table 3. Simulated components of the ground-water budget for the alluvial aquifer under steady-state conditions, northwestern Kentucky, November 1991

\begin{tabular}{|c|c|c|}
\hline Budget component & $\begin{array}{c}\text { Amount } \\
\text { (million cubic } \\
\text { feet per day) }\end{array}$ & Percentage \\
\hline \multicolumn{3}{|l|}{ Recharge } \\
\hline 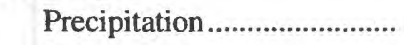 & 0.96 & 26.1 \\
\hline 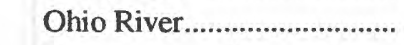 & 2.48 & 67.6 \\
\hline Flow across valley wall ........ & .23 & 6.3 \\
\hline 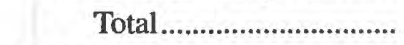 & 3.67 & 100 \\
\hline \multicolumn{3}{|l|}{ Discharge } \\
\hline 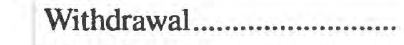 & 3.14 & 85.8 \\
\hline 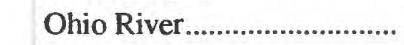 & .05 & 1.4 \\
\hline 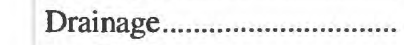 & .47 & 12.8 \\
\hline Total & 3.66 & 100 \\
\hline
\end{tabular}

terms associated with general head boundaries. Each input parameter was varied a specified amount from the calibrated value used in the steady-state simulation. The amount of variance was determined by estimates of the probable range of data. Because each change in parameter value was tested separately, the additive effects of changes for different combinations of parameter values were not considered.

Simulated hydraulic heads at 19 wells were compared statistically to the measured water levels from November 1991. Head responses are reported as the RMSE of residuals for select wells in heavily pumped areas, select wells in non-pumped areas, and all wells. The results of the sensitivity analysis in terms of percentage of changes of RMSE are shown in figure 13. A positive percentage of change in RMSE indicates that the match between measured and simulated heads from a sensitivity-analysis run is worse than the RMSE of the calibrated model, whereas a negative percentage of change in RMSE indicates the simulated heads match the measured heads better than the calibrated model.

The areal distribution of hydraulic conductivities was arbitrarily based on well logs and fence diagrams published in Gallaher (1963). The sensitivity of the model to changes in conductivity was evaluated by varying all conductivities within a range of \pm 50 percent of the calibrated conductivities. The results of the analysis indicate that the head residuals are more sensitive to decreases in hydraulic conductivity than an increase. Residual heads for wells unaffected by local pumping display the sensitivity to decreases in hydraulic conductivity, but results show a better match would be possible with a 10 percent increase in hydraulic conductivity.

The head residuals in the heavily pumped areas, however, were not as sensitive to changes in hydraulic conductivity.

Recharge from precipitation was estimated to $3.5 \mathrm{in} / \mathrm{yr}(0.0008 \mathrm{ft} / \mathrm{d})$ for the calibrated model. For the sensitivity analysis, an error of \pm 37 percent $( \pm 0.0003 \mathrm{ft} / \mathrm{d})$ was assumed in the measurement of 

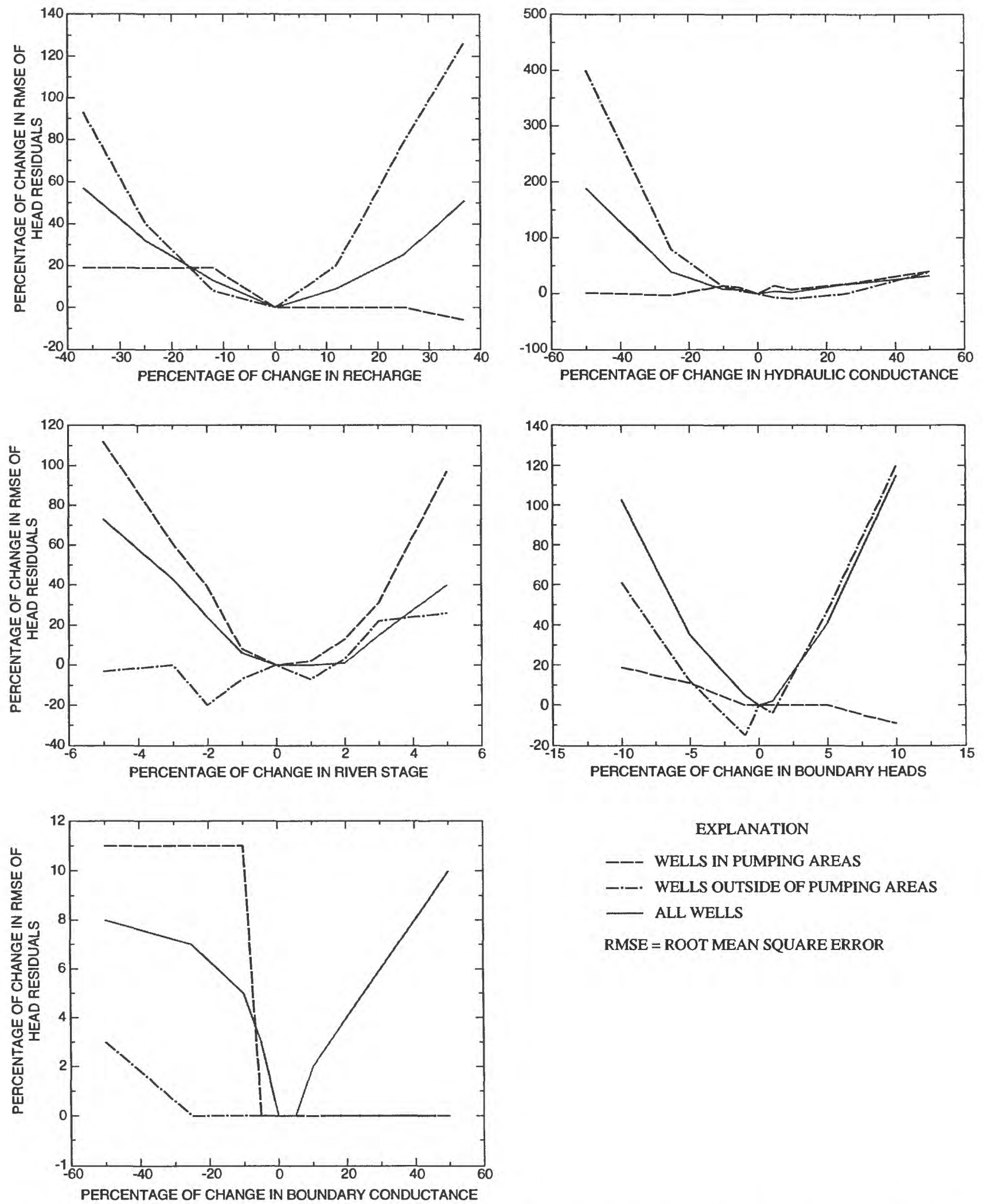

EXPLANATION

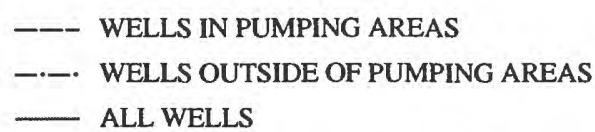

RMSE $=$ ROOT MEAN SQUARE ERROR

Figure 13. Sensitivity of simulated heads to changes in recharge, hydraulic conductance, river stage, boundary heads, and boundary conductance, Owensboro area, northwestern Kentucky. 
recharge from precipitation. Hydraulic heads simulated by the model are more sensitive to changes of recharge in the non-pumping areas than in the heavily pumped well fields.

The Ohio River is the most dominant hydrologic feature present in the study area. It is a constant source of recharge for nearby pumping wells. For the model simulation, the river is simulated as a constant head boundary. Even though the river stage was assumed to be known, it was varied $\pm 5 \mathrm{ft}$ to analyze the sensitivity of the model. The effects of the error are most noticeable for simulated heads in the heavily pumped areas near the river. A decrease in river stage caused an increase in the RMSE due to a lack of water available to meet the imposed groundwater withdrawals. Likewise, an increase in river stage, and consequently an overabundance of available water, caused an increase in the RMSE.

Model boundaries other than the Ohio River were simulated as general head boundaries. Hydraulic conductivity of the interface between the aquifer cell and the boundary was varied \pm 50 percent for the sensitivity analysis. The effects from these changes did not vary greatly, generally less than 15 percent change in the RMSE. However, the model was sensitive to changes in the exterior heads of \pm 10 percent for the discharge calculations. The model is more sensitive to changes in the exterior heads in the non-pumping areas and overall than in the heavily pumped well fields.

Ground-water withdrawals by area users was well investigated and assumed to be known. The pumpage amounts were not varied for the sensitivity analysis.

\section{Model Limitations}

Limitations affecting the application of the ground-water-flow model and the interpretation of subsequent model results must be known and fully considered for appropriate application of the model and accurate simulation of the natural flow system. The amount and detail of hydrogeologic knowledge of the natural system, the initial scale of the ground-water-flow model, and the inherent limitations of numerical models restrict the uses of the ground-water-flow model. But with proper application and an understanding of the limitations, the ground-water-flow model is a viable investigative tool capable of simulating regional ground-water flow through the alluvial aquifer.

Grid design, boundary conditions, and calibration data all rely on hydrogeologic knowledge of the natural flow system. For this assessment of hydrogeologic conditions, one synoptic water-level measurement was made for model calibration data. Boundary conditions and surface-water/groundwater interaction, particularly with the Ohio River, were based on available published data, county/project file data from previous investigations, and the conceptual model. The grid design was based on the anticipated ground-water flow as presented by the conceptual model and on the spatial distribution of available control points. Hydrogeologic characterization of the natural system can never be complete, but model accuracy should improve with the incorporation of additional data.

Scale limitations should also be considered when using the model to predict migration of hazardous material or the response of the groundwater-flow system to changes in applied stresses. The response of the ground-water-flow system to largescale changes, such as \pm 50 percent change in ground-water pumpage or the addition of 1 inch of recharge from precipitation infiltration, can be simulated with a relative assurance of accuracy. But the response of the ground-water-flow system to small-scale changes, such as rearranging the pumping scenario within the OMU well field, could not be accurately simulated. A more site-specific model would be required for this type of application.

Lastly, the ground-water-flow model is an attempt to represent numerically the natural flow system. User defined numerical approximations and convergence tolerances allow the model to simulate 
the natural system and its response to changes in stresses within a predetermined range of accuracy. No ground-water-flow model can completely recreate the natural system in a numerical representation.

\section{Application of the Ground-Water Flow Model}

The calibrated ground-water-flow model was used to delineate recharge and discharge boundaries and to estimate flowpaths and traveltimes of particles placed in the flow system. Knowledge of recharge areas for ground-water withdrawal wells could be used in the management of the ground-water resource and in the delineation of wellhead protection areas. Likewise, particle flowpaths and traveltimes could provide a portion of the information needed to assess the effect of potential releases from hazardous materials storage facilities in the modeled area.

The particle-tracking program MODPATH (Pollock, 1989) was used to illustrate the simulated ground-water-flow system. For this application, one particle, representing an infinitesimal volume of ground water, was placed at the center of all active cells in the model grid. Each particle progressed through the ground-water-flow system until a discharge boundary was encountered. Cells discharging to the same boundary were grouped to produce a map identifying the contributing areas (fig. 14). The tracking was designed to allow particles to pass through cells with weak sinks. A model cell with a weak sink has a portion of its water discharging through the boundary but also contributes flow to an adjacent cell. Because the delineation of the contributing area to the public-water supply wells of OMU was the primary concern, weak sinks were eliminated, thus allowing the maximum number of particles to discharge to strong sinks, such as the OMU wells and the Ohio River.
The aquifer's response to different resourcemanagement decisions can be evaluated by applying the calibrated ground-water-flow model. Changes in pumping rates for current ground-water users, introduction of new ground-water users, and changes in environmental factors such as the amount of precipitation and fluctuations in the Ohio River stage can be combined to determine potential effects on ground-water levels, flowpaths and traveltimes, and the size and shape of contributing areas of discharge boundaries and ground-water withdrawal wells. The resulting contributing areas for the simulation of the November 1991 conditions are shown in figure 14. Most of the contributing areas share a common boundary as ground-water withdrawal wells extend to the Ohio River, where surface water is induced by the pumping of the wells. By changing the applied stresses in the model, new contributing areas could be calculated and delineated for evaluation.

Time-of-travel estimates were computed by MODPATH for particles discharging to the OMU well field. Bands of equal time of travel are shown in figure 15. Water induced from the Ohio River is estimated to have a traveltime less than two years. Additional hydrologic and geologic data characterizing this area are needed to better estimate traveltimes of induced river water to the public watersupply wells. The time required for water to move through the unsaturated zone above the aquifer is not included in these estimates.

Estimations of contributing areas to wells, the delineation of flowpaths, and the calculation of time of travel for particles are subject to error. The limitations of particle tracking are directly related to the uncertainty in parameter estimations and incorrect model design. Contributing areas to wells are only approximate because assumptions are made in estimating parameters characterizing the alluvial deposits and a limited number of particles are used (one particle per cell). 


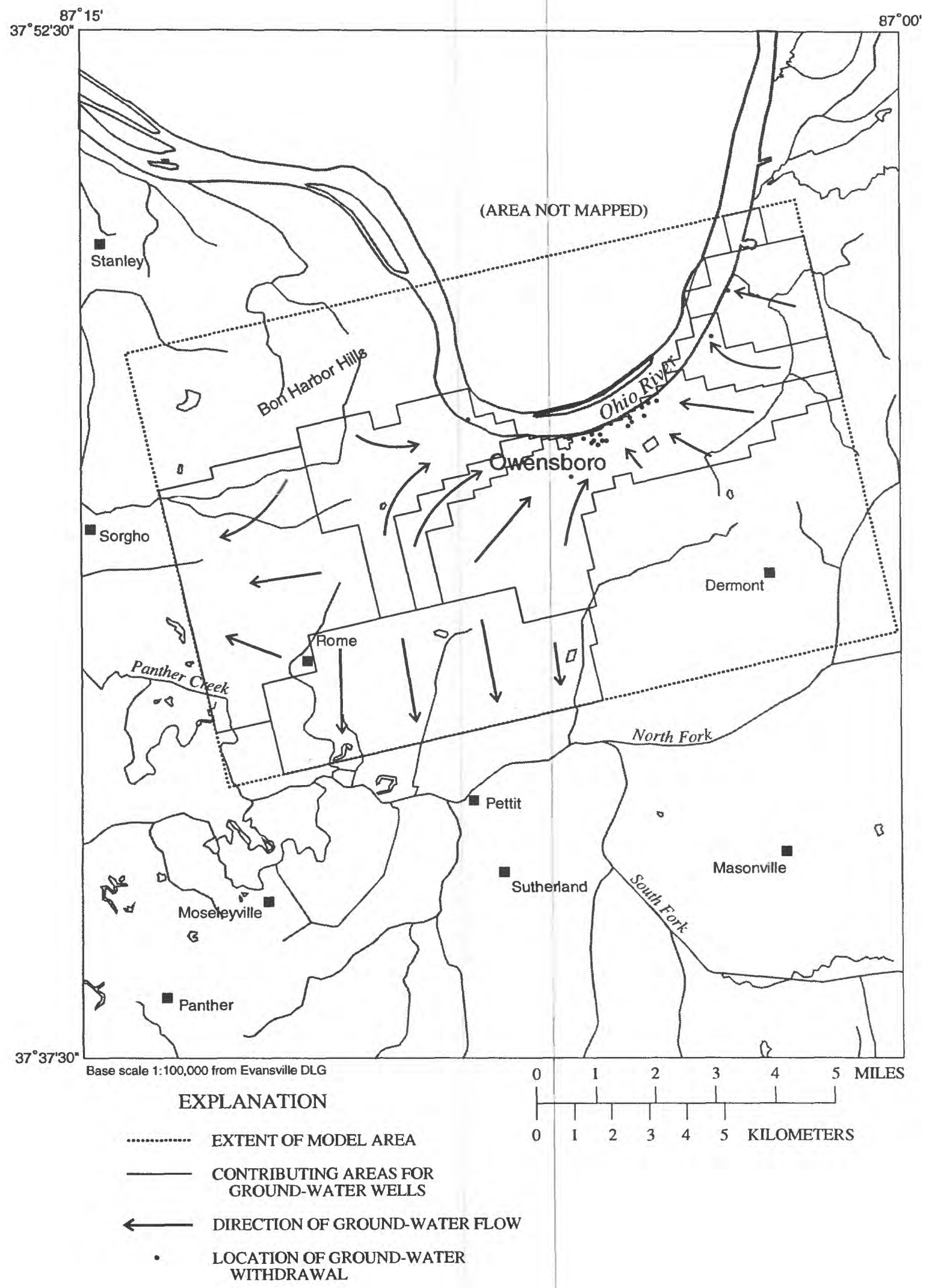

Figure 14. Contributing areas of discharge boundaries computed with the calibrated model, Owensboro area, northwestern Kentucky. 


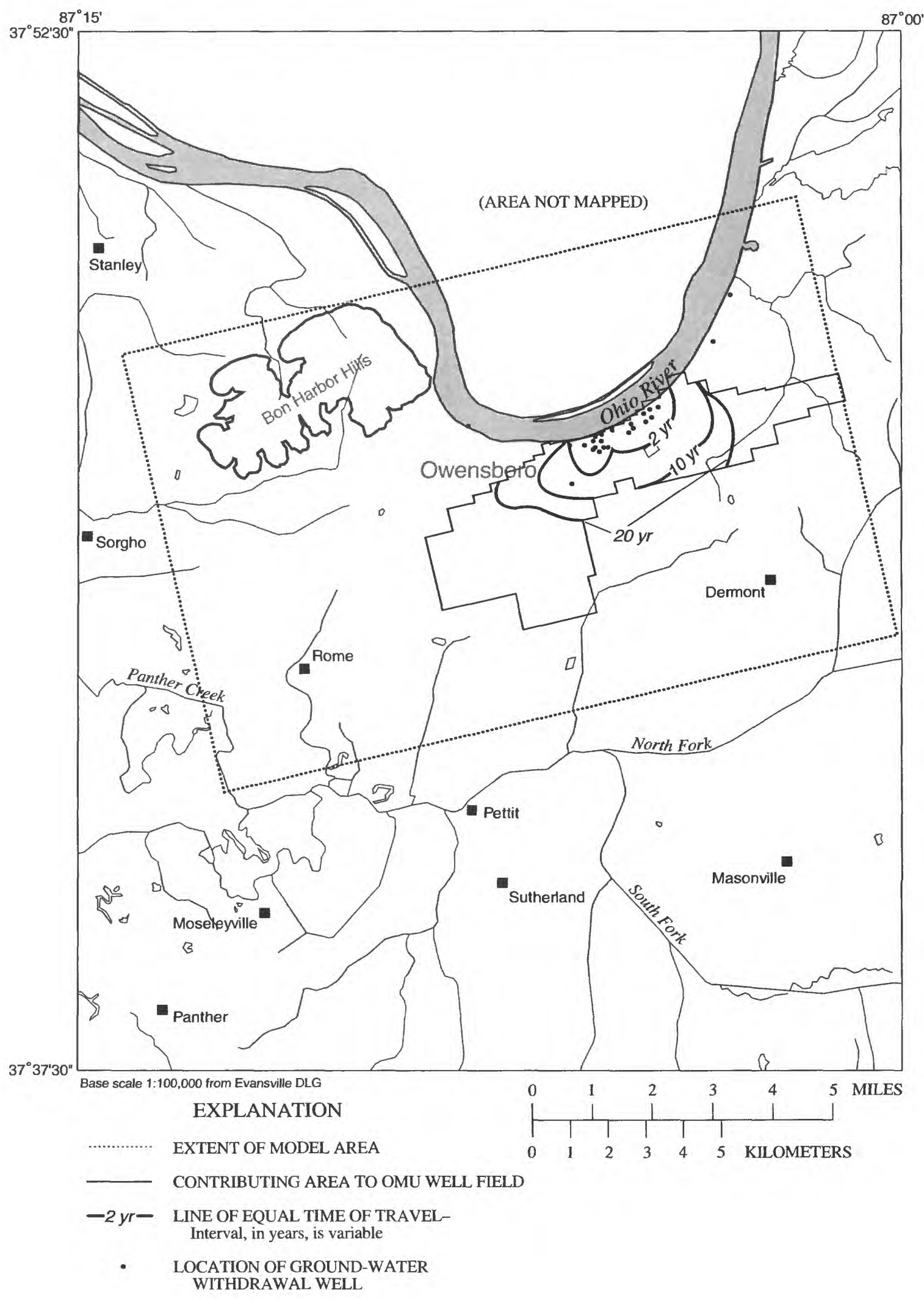

Figure 15. Traveltime computed for the Owensboro Municipal Utilities contributing area. 


\section{SUMMARY}

The alluvial aquifer at Owensboro, Kentucky, consists of glacial-outwash deposits of Illinoian and Wisconsin age underlain by shales of Pennsylvanian age. Dissection of the bedrock surface by the Ohio River during the Pleistocene epoch was uneven and is characterized throughout the study area by buried bedrock hills, valleys, benches, and cusps. The alluvial deposits are composed of upper, fine-grained deposits underlain by coarser sands and gravels. The fine-grained deposits generally are 30 to 50 -foot thick near the river; the layer thickens and becomes mixed with tributary alluvium as it proceeds from the Ohio River towards the bedrock valley walls. The basal layer is composed of boulder-sized material near the river to sand or sand and gravel throughout the rest of the study area.

Precipitation is the ultimate source of all water in the hydrologic system, but losses from overland runoff, evapotranspiration, and soil moisture uptake reduce the available amount of precipitation for recharge. As ground water migrates through the system, it eventually discharges to the Ohio River and to other other streams, or is pumped from wells. Sustained yields to wells along the Ohio River are as high as $1,000 \mathrm{gal} / \mathrm{min}$, and many wells yield 700 to $800 \mathrm{gal} / \mathrm{min}$. Transmissibility coefficients have been calculated at several sites along the river in the study area. Values range from 23,000 to more than 55,300 ( $\mathrm{gal} / \mathrm{d}) / \mathrm{ft}$.

The altitude of the potentiometric surface of the alluvial deposits generally decrease from the valley walls to discharge areas, namely the Ohio River and its ancestral channel. The saturated thickness of the alluvial deposits ranges from 60 to $120 \mathrm{ft}$ and decreases towards the valley walls. Interruptions in this pattern occur near the Owensboro Municipal Utilities well field and other heavily pumped areas.
Ground-water gradients are reversed and surface water from the Ohio River is induced into the outwash in these areas of heavy pumpage.

The ground-water-flow system was simulated using a two-dimensional, steady-state, one-layer flow model.The model simulates steady-state conditions for data collected during November 1991 and was calibrated to 19 measurements of head. The model simulation indicates ground water enters the system primarily from induced infiltration from the Ohio River (68 percent), precipitation (26 percent), and head-dependent boundaries ( 6 percent). The ground water exits the modeled system by ground-water pumpage (86 percent), flow over head-dependent boundaries (13 percent), and flow to the Ohio River (1 percent). A sensitivity analysis of the input parameters indicated that the model simulation is most sensitive to decreases in horizontal hydraulic conductivity and changes in external heads for the head-dependent boundaries.

Estimates of contributing areas to ground-water withdrawal wells were made on the basis of head gradients and ground-water-flow velocities as simulated by the model. Contributing areas to wells, the delineation of flowpaths, and the calculation of time-of-travel particles are subject to error.

The ground-water-flow model of the Owensboro area is an attempt to numerically represent the natural flow system. The acquisition and incorporation in model simulations of more information characterizing and quantifying boundary conditions, long-term water-level trend data, and better defined hydraulic conductivity values based on lithologic data would improve the accuracy of the simulations. Quantification of the amount of recharge derived from precipitation and more complete ground-water pumpage records could improve the estimates of recharge and stresses affecting the geohydrologic system. 


\section{REFERENCES CITED}

Carpenter, G.L. Jr., 1971, Map showing bedrock topography and subcrop of selected beds beneath alluvial deposits of part of the Owensboro West quadrangle, in Daviess County, Kentucky: U.S. Geological Survey Miscellaneous Geologic Investigations Map I-633, scale 1:24,000.

Dumouchelle, D.H., Schalk, C.W., Rowe, G.L., and de Roche, J.T., 1993, Hydrogeology, simulated groundwater flow, and ground-water quality, Wright-Patterson Air Force Base, Ohio: U.S. Geological Survey WaterResources Investigations Report 93-4047, 152 p.

Gallaher, J.T., 1963, Geology and hydrology of alluvial deposits along the Ohio River in the Lewisport and Owensboro areas, Kentucky: U.S. Geological Survey Hydrologic Investigations Atlas HA-74, 2 sheets, scale $1: 24,000$.

Gallaher, J.T., and Price, W.E. Jr., 1966, Hydrology of the alluvial deposits in the Ohio River Valley in Kentucky: U.S. Geological Survey Water-Supply Paper 1818, $80 \mathrm{p}$.

Goudarzi, G.H., and Smith, A.E., 1971, Geologic map of part of the Owensboro West quadrangle, in Daviess County, Kentucky: U.S. Geological Survey Geologic Quadrangle Map GQ-890, scale 1:24,000.

Kentucky Cabinet for Economic Development, 1991, Resources for Economic Development-Owensboro, $33 \mathrm{p}$.

Maxwell, B.W., and Devaul, R.W., 1962, Reconnaissance of ground-water resources in the Western Coal Field Region, Kentucky: U.S. Geological Survey WaterSupply Paper 1599, 34 p., 3 plates.
McDonald, M.G., and Harbaugh, A.W., 1988, A modular three-dimensional finite-difference ground-water flow model: U.S. Geological Survey Techniques of WaterResources Investigations, book 6, chap. A1, 528 p.

Orzol, L.L., and McGrath, T.S., 1992, Modifications of the U.S. Geological Survey modular, finite-difference, ground-water-flow model to read and write geographic information system files: U.S. Geological Survey OpenFile Report 92-50, 202 p.

Pollock, D.W., 1989, Documentation of computer programs to compute and display pathlines using results from the U.S. Geological Survey modular three-dimensional finite-difference ground-water-flow model: U.S. Geological Survey Open-File Report 89-381, 188 p.

Ray, L.L., 1965, Geomorphology and Quaternary geology of the Owensboro quadrangle Indiana and Kentucky: U.S. Geological Survey Professional Paper 488, 72 p.

Rorabaugh, M.I., 1949, Progress report on the ground-water resources of the Louisville area, Kentucky, 1945-49: City of Louisville and Jefferson County, Ky., 64 p.

Smith, A.E., 1971, Map showing bedrock topography and subcrop of selected beds beneath alluvial deposits of the Panther quadrangle, Daviess County, Kentucky: U.S. Geological Survey Miscellaneous Geologic Investigations Map I-598, scale 1:24,000.

Smith A.E., 1969, Map showing bedrock topography and subcrop of selected beds beneath alluvial deposits of the Sutherland quadrangle, Daviess County, Kentucky: U.S. Geological Survey Miscellaneous Geologic Investigations Map I-596, scale 1:24,000.

Walker, E.H., 1957, The deep channel and alluvial deposits of the Ohio Valley in Kentucky: U.S. Geological Survey Water-Supply Paper 1411, 25 p., 6 plates. 